\title{
Are Branch Banks Better Survivors? Evidence from the Depression Era
}

\author{
Mark Carlson \\ Federal Reserve Board
}

It is widely argued in the literature on the Great Depression that the prevalence of unit banks aggravated the problem of financial instability that afflicted the country. This paper tests the theory that more widespread branch banking would have reduced financial turbulence in the United States by examining the survival of individual branch and unit banks. Results indicate that instead of being more likely to survive, branch banks were more likely to fail. Further investigation suggests that this higher failure rate occurred because branch banks systematically held riskier portfolios than unit banks.

\footnotetext{
* Federal Reserve Board; $20^{\text {th }}$ and C Streets, NW, Stop 86; Washington, DC 20551. Mark.A.Carlson@frb.gov. I am grateful to Gregory Duffee, Barry Eichengreen, Chris Meissner, James Pierce, Christina Romer, and Malinda Ruzicka as well as seminar participants at UC Berkeley, Rutgers University, and the Federal Reserve Board for their helpful comments and suggestions. I am also indebted to the North Carolina Office of Commissioner of Banks for their generous assistance collecting data. The views presented are solely those of the authors and do not necessarily represent those of the Federal Reserve Board or its staff.
} 
In recent years, branch banking has been promoted as a way of increasing the stability of banking system. The reasoning is straightforward. Branching facilitates geographic diversification. Diversification in turn reduces the risk that a geographically focused idiosyncratic shock will affect a bank severely enough to cause it to fail (Southworth 1928; Gart 1994). The promise of increased stability was one of the reasons for recent legislation (such as the Riegle-Neal Interstate Banking and Branching Efficiency Act of 1994) deregulating the banking sector to allow branching.

While the creation of branch bank networks has been heralded as a source of stability, the lack of branch banking has often been blamed for the prevalence of banking crises in the United States. Friedman \& Schwartz (1963) blamed the high failure rate of United States banks during the Depression on the lack of branching. Recent work by Grossman (1995) suggested that countries with extensive branch networks were less likely to experience a banking crisis in the 1930's. Wheelock (1995) found that even in the United States, states that had more branch banks tended to have lower failure rates during the Depression. Focusing on a more modern crisis, Gart (1994) suggested that interstate branching might have mitigated the large losses of the savings and loan crisis of the 1980's.

This paper tests the conventional wisdom that allowing banks to establish branches increases their ability to withstand shocks and reduces failures within the banking sector. Specifically I test whether branching increased the probability of survival or the length of survival of individual banks in the first four years of the Great Depression. By using data for individual banks, I am able to separate the effect of branching from effects of associated characteristics, such as size of the bank. The first four years of the Depression are used because this is the most recent period in the United States where both unit and branch banks existed, large numbers of banks failed, and because the debate over branching features so prominently in the literature on this period.

The results are striking. Branch banks are found to be less likely to survive and to survive for shorter periods of time. Because these results are so different from those of previous work, additional investigation is undertaken to determine why they are obtained.

Following recent work by Hughes, Lang, Mester, and Moon (1996), a model is constructed focusing on how banks adjust the risks they take to changes in their risk-return tradeoff. Banks choose the amount of reserves held to meet deposit withdrawals, or the level of 
liquidity risk. Branch banks have a different risk-return tradeoff, since they are able to diversify away idiosyncratic withdrawals and smooth the level of deposits. Because they face this different tradeoff, branch banks are shown to hold fewer reserves and more loans than unit banks. This implies that branch banks will have a higher return on capital, lower exposure to idiosyncratic shocks, and a higher exposure to systemic shocks. During normal times branch banks would be safer; however, if the bank runs of the Great Depression were systemic shocks, branch banks would have been more susceptible to them because of their asset and liability holdings.

Several implications of this explanation are tested. I show that branch banks held a smaller share of liquid reserves against their liabilities than did unit banks. Branch banks are also more likely to fail due to a bank run. To test whether this model explains the failure patterns of branch banks, a measure of below average reserves to demand deposits is included in the analysis of survival length. When this measure is included, branching no longer has a significantly negative effect on survival.

The conclusion is therefore not that branching is detrimental. Instead, it is that the effect on a bank's stability from branching depends on the choices made by individual bankers about whether to use the diversification opportunities of branching to increase returns or decrease risk. This study suggests that many branch bankers during the 1930's chose to increase returns, a decision that increased their risk of failure during the global shock of the Great Depression. Also, the results of this paper do not suggest that the evidence of increased stability in banking systems that allow branch banking is incorrect. Rather they simply indicate that any increase in stability is due to a reason other than that banks which have established branches are less risky.

The rest of this paper is organized as follows. Section 2 discusses why branching diversifies banks' portfolios and why this should result in reduced risk of failure. Section 3 reviews previous work on branch banks. Section 4 presents the data that are used in this paper and the tests for differences in survival between branch and unit banks. Section 5 discusses rejected explanations. Section 6 presents and tests a potential explanation for the finding that branch banks might be more likely to fail. Efforts to reconcile the findings of this paper with those of prior studies are presented in Section 7, the conclusion.

\footnotetext{
${ }^{1}$ Both the model and the measure of reserves to deposits focus on the liquidity risk of the bank. Presumably this is indicative of the bank's attitude toward other types of risk as well.
} 


\section{Diversification Through Branching}

The literature describes three ways in which branching might expand a bank's opportunity for diversification. First, branching can expand the types of industries and/or sectors to which a bank might lend (Gart 1994). Businesses in the same industry tend to clump together. If banks provide loans mostly to industries in their immediate area, which may be true for reasons having to do with information or access, then branching in different areas will provide a bank with opportunities to invest in different industries. If different industries are affected by different shocks, such diversification would reduce a bank's exposure to a downturn. 2

Second, branching may diversify a bank's portfolio with respect to spatial shocks (Southworth 1928; Wheelock 1992). Again, assume that banks mainly loan to nearby areas. If different regions are affected by different shocks, for example weather shocks in agricultural regions, then branching increases diversification because shocks in any one location do not effect a bank's entire portfolio.

Industrial and spatial diversification both affect the asset side of the balance sheet; however, branching also offers opportunities for diversification on the liability side of the balance sheet (White 1984). If depositors place deposits in nearby banks (for reasons of convenience), and if depositors who differ by location also differ in their behavior, then geographically diverse branch banks would have a more diversified liability base. It may be that depositors in different locations need cash at different times, so that the bank's total liabilities fluctuate less over time (Miron 1986). It may also be that depositors in different locations might have different information sets that would cause them to panic. In this case, having branches would reduce the probability that runs would affect the bank's entire liability portfolio.

\section{Related Literature}

The idea that branch banking increases the stability of the banking system and generally benefits the community has been held by scholars since before the Great Depression. Preston (1924) and Southworth (1928) discussed the idea that branch banking might increase the stability of the banking system. They suggested that branching would increase the diversification of a

\footnotetext{
${ }^{2}$ Winton (1999) suggests that this may depend on how carefully the bank monitors its loans and the severity of the downturn.
} 
bank's portfolio and reduce exposure to risk. Southworth bolstered this claim by noting that branch banking systems resulted in stable and secure banking systems in other countries.

A variety of empirical papers have tested the idea that branch banking increases diversity, reduces risk, and thus reduces the probability of a banking crises. Bordo (1985) compared five industrial nations, across time and noted that the United States was both more prone to banking crises and the only country with a banking system characterized by small unit banks. He concluded that the lack of an extensive branch system might be an important reason for the prevalence of banking crises in the United States. Grossman (1994) compared 25 countries during the Great Depression. He found that countries whose banking systems were comprised largely of banks with large branch networks were less likely to experience banking crises. Other studies have focused on the experience of different states in the United States. Wernette (1932) compared the failure rates of state banks across states for the period June 30, 1930 to June 30, 1931. He noted that California had one of the lowest failure rates in the nation, and was also the state with the broadest system of branching. Wheelock (1995) studied the importance of several factors affecting bank failure rates from 1929-1932. One of his conclusions was that states that had more branches tended to have lower failure rates. Mitchner (2000) studied whether different regulatory policies affected the failure rates of banks and found that states that explicitly legalized branching had lower failure rates than states that did not.

Branch banks are thought to be safer because geographic diversification reduces the impact of idiosyncratic shocks. Cherin and Melicher (1988) carried out a study to test this hypothesis. They showed that the average returns to the banking industry from 1967-1977 more closely matched the returns of branch banks than unit banks. They concluded that the geographic diversification of branch banks had successfully reduced the banks' exposure to idiosyncratic risk.

\section{The Survival of Branch and Unit Banks}

In this section, the results of testing the hypothesis that branch banks are better survivors during a crisis are presented. To more clearly interpret the results, it is useful to first describe the data, the definition of failure, and what is meant by branching.

\footnotetext{
${ }^{3}$ These findings are different than those reported here. A possible reconciliation is discussed in the conclusion.
} 


\section{A. The Data}

The data that is used to examine the survival patterns of branch and unit banks comes from the annual reports of the bank regulators from various states. Information on individual state banks is collected from California, Maryland and North Carolina, three of the ten states that allowed branch banking in the 1920's. The combined sample includes 665 banks. Of the other states that allowed statewide branching, the annual reports of Georgia, South Carolina, Virginia, and Wyoming list very few branch banks, Delaware and Rhode Island may not be large enough to offer geographic diversification, and data for Arizona is not available.

Balance sheet information on assets and liabilities is collected for all banks at the time closest to, but not after, June 30, 1929. This is the date closest to the start of the Great Depression yet still prior to the stock market crash that is available in the annual reports. Information about the number and location of each bank's branches and the number of years that the bank had been in existence prior to 1929 is also collected.

The sample consists solely of incorporated state chartered banks. Several types of state banks appear in the reports of regulators: savings banks, commercial banks, combination commercial and savings, and combination commercial, savings and trust banks. Combination commercial and savings banks are the most common. Savings banks are excluded from the sample because they were treated differently than other banks by legislation and regulators.

It should be noted that while branch banks were subject to many of the same regulations as unit banks, such as supervision, required reserves, and liability of stockholders, they were subject to slightly different capital requirements. For each branch that banks established, they had to put up an additional dollar amount of capital. The amount of additional capital depended on whether the branch was an inter- or intra- city branch and on the population of the city in which the branch was established. In general, the additional capital was equal to the minimum of capital required to open a new bank in the new city. Because much of the variation in capital requirements was for small towns, and because Census estimates are not available for many

\footnotetext{
${ }^{4}$ Age of bank is not available for Maryland.

${ }^{5}$ In California, savings institutions faced more restrictions on the loans that could be issued; "It is desirable to reiterate that there is fundamentally a careful limitation on the investment by savings banks or savings departments of the funds received by them." (Annual Report of the Superintendent of Banks of the State of California for 1928, p.10) Maryland reports savings and commercial banks separately, though the reason for the separation is not described.
} 
small towns, it cannot be determined whether minimum capital requirements were more or less likely to be binding for branch banks than for unit banks.

The county of the bank's main office is matched to county level 1930 census data to provide information on the area surrounding the banks. Information is available on the size and urban/rural distribution of the population as well as the number of firms, number of farms, and value of crops produced in each county.

\section{Creating the Branch Variables}

The most important variables in this paper are those concerning branching. Banks may have branches either in the city with the home office (home branches) or outside the city of the home office (outside branches). It is not clear that home branches offer the same diversification opportunities as outside branches, thus the two types of branches are differentiated in the analysis. Banks that had branches are placed into one of two groups, "home branching banks" and "outside branching banks". Banks that branch, but only in the city of the home office, are assigned to the group "home branching banks". Banks that had at least one outside branch are assigned to the "outside branching banks" group. Assignment to a group is indicated by a dummy variable. Banks with both home and outside branches, since they are able to gain whatever benefits that outside branches offer, are grouped with other outside branching banks.

For the remainder of this paper, the term branch bank will be used to refer to an outside branching bank and the term branch will be used to refer to a branch outside the city of the home office. Home branching banks and home branches will be referred to specifically.

Table 1 shows the distribution of banks by state and by the number of cities in which the banks have branches. Most banks have no outside branches. North Carolina has the most banks overall. The share of banks that do have branches is fairly even across states, though California has three of the four largest banks in terms of number of outside branches.

The largest branch banks in California and Maryland branched fairly thoroughly throughout their respective states. The second and third largest branch banks in California are regional banks centered around San Francisco and Los Angeles respectively. Among banks with only one or two branches there is great diversity of geographic dispersion, with some banks establishing branches 6 miles away and some maintaining branches 160 miles away.

Some tests below use measures of branching other than the dummy for having an outside branch in an effort to capture measures of geographic dispersion. The alternative measures 
include using the log of the number of cities in which a bank has branches and the average distance to a bank's branches.

\section{Other Variables}

Some simple control variables are created: state dummies, to control for individual state effects, and bank type dummies, to control for whether the bank had a savings or trust component.

Branch banks tend to be larger than unit banks, so it important to control for size in order to determine the effect of branching. Size is measured as total assets logged and measured in tens of thousands of dollars. Insofar as having more assets offers more diversification opportunities, larger banks should be more likely to survive.

A variety of measures of how the bank distributed its assets and liabilities are constructed. To normalize these measures, they are all defined as a share of total assets. The share of total assets consisting of loans is included as a measure of potential profits as well the share of assets that might go into default in the Depression. Stocks and bonds were relatively liquid assets and were used as a form of secondary reserves. A higher share of these securities should increase survival. The book value of net worth (the sum of capital, surplus, and undivided profits) of the bank is included to measure the profitability of the bank at the start of the sample period. It would be preferable to have market value of net worth because the book value often overstates the value of capital, however, market value of net worth is unavailable for many of these banks. Interpretation of this variable is also somewhat unclear. Capital and surplus are safe guards against losses. Low values could indicate either that the bank is very risky or so safe that no one expects losses. Rediscounts were often taken as a sign that a bank was in trouble, so the fraction of liabilities from rediscounts is included. ${ }^{6}$

The shares of total liabilities/assets composed of demand deposits, time deposits, and cash are also constructed. Since none of these measures affected the results, they are excluded from the final regressions.

The "experience" of the bankers is proxied by the age of the bank (the number of years the bank charter had been in existence before 1929). Because age is missing in Maryland, a dummy for the bank being under five years old - or a new bank - is constructed. This variable

\footnotetext{
${ }^{6}$ Rediscounts were often short term and carried high interest rates. Rediscounting large numbers of loans was taken by regulators as a sign of trouble (White, 1984).
} 
has the advantage that it can be constructed for all banks by checking whether the bank was included in the 1924 annual reports. ${ }^{\text {. }}$

Variables that describe the area around the bank are included to control for location effects. The fraction of the population in urban areas is included to control for the types of clientele that a bank might have. Farmers may have different needs than businesses found in larger cities. The number of firms in the county and an index of agricultural diversity are included in the tests to measure the opportunities for diversification available in the area. ${ }^{\text {B }}$

An effort is made to control for local market competition and the market share of the bank. Competition is measured using the number of banks in the county. Market share is measured as the share of county assets owned by the bank. ${ }^{6}$ Neither of these variables affects the results and they are dropped from the final analysis.

Table 2 presents various summary statistics about the assets and liabilities of different types of banks.

\section{Determining Failures}

The annual reports for 1934 are examined to determine if the bank still existed on March 1, 1933. If so, it is considered a survivor. If the bank had been placed in a receivership, it is considered a failure and the closure date of the bank is used the failure date.

A variety of issues cloud the distinction between a failed bank and a successful bank. Banks may have been voluntarily liquidated, suspended but allowed to reopen, or merged with another bank. Banks that were voluntary liquidated are considered to be not economically viable and are treated as failures. Presumably, owners would not liquidate a profitable bank, while banks that were in danger of causing losses to their owners, would have been liquidated. Banks that suspended operations before March 1, 1933 but reopened prior to the end of 1933 are

\footnotetext{
${ }^{7}$ Tests using just California and North Carolina find that linear measures of age are insignificant. The discrete measure employed here provides a better fit to the data. The findings are robust to a reasonable choice of the number of years.

${ }^{8}$ Number of firms is the sum of the farms, manufacturing establishments, and retail establishments. The variable is measured in tens of thousands of firms. Agricultural diversity is included because agricultural failure and agricultural price collapse are often cited as reasons for bank failure in the Depression (Temin 1976).

${ }^{9}$ This measure of market share is somewhat problematic however, because some counties have only one bank headquartered there but have several branches of large banks. Since, there is no information on the assets possessed by the branches, it is impossible to accurately measure the market share of the banks that are headquartered there.

${ }^{10}$ An end date prior to the National Banking Holiday and introduction of deposit insurance is used so that bank closings are more comparable. The results are robust to the choice of end date.
} 
considered economically viable and are treated as survivors. Reassuringly, these two groups of banks are not large and the results are robust to alternative treatments.

A number of banks no longer existed in March 1933 because they were purchased by or merged with another bank. Several treatments have been used in the literature to deal with mergers. ${ }^{11}$ Rather than select a single treatment, a variety of treatments are considered in this paper and the results are compared across treatments. The treatments that are used are dropping banks that merge from the sample, treating them as failures, and censoring them at the date they merged. The number of mergers is large and the treatment of this group affects the significance level, though not direction, of the results. Because the results depend on the treatments of merging banks, an analysis is conducted to determine the most appropriate treatment.

Table 2 breaks down survival by type of bank.

\section{B. Survival of Branch Banks}

The central hypothesis tested in this paper is that branch banks were better able to survive the shocks of the early 1930's than unit banks. This general hypothesis is divided into two, more precise, hypotheses. The first hypothesis, that branch banks were more likely to survive than unit banks, is tested using logit analysis. The second hypothesis, that branch banks survived longer than unit banks, is tested using duration analysis.

Were branch banks more likely to survive?

The first test is whether branch banks were more likely to survive than unit banks. The expected outcome is that having branches increases the likelihood of survival.

This test is conducted using a logit regression. Two specifications of independent variables are used. The first of these specifications includes only branch, state, and type dummies while the second adds a variety of portfolio and location characteristics. ${ }^{1}$ Banks that merged were treated in two ways: by dropping them from the sample, and by considering them to have failed. The results are presented in Table 3.

The results are striking. Having a branch reduced the probability of survival when mergers are dropped. Branching has no effect when mergers are treated as failures. There is no evidence that branching increases the probability of survival. The point estimates, when each bank's assets and liabilities are taken into account, suggest that branch banks have a 15\% higher

\footnotetext{
${ }^{11}$ Alhadeff \& Alhadeff (1970) treat mergers are failures while Cherin \& Melicher (1988) drop mergers from their sample.

${ }^{12}$ This specification choice was determined by a likelihood ratio test.
} 
chance of failure when mergers are dropped and an $8.5 \%$ higher chance of failure when mergers are treated as failures.

The other variables generally have the expected effect. Larger banks are more likely to survive. Reductions in the probability of survival are associated with being a new bank, having more loans, and having a higher share of rediscounts in liabilities. Being in a county with more non-financial firms also decreases the probability of survival.

Did branch banks survive longer?

The next hypothesis is that banks with branches survived longer than unit banks.

Since the dependent variable is the length of survival and the end of the survival spell is not observed, duration analysis is the appropriate econometric technique. (See Cox and Oakes 1984 for a detailed presentation of duration analysis.)

The sample period begins June 30, 1929. The dependent variable is the number of days the bank survived after that date. The sample period ends March 1, 1933.

Figure 1 plots the Kaplan-Meier survival function, which shows the fraction of the sample that has not failed. This non-parametric test is a convenient way of displaying the data without imposing any restrictions. The figure shows the survival functions for outside branching, home branching, and unit banks so that survival patterns may be compared.

Figure 1 indicates that outside branching banks have a higher failure rate than unit banks suggesting, somewhat surprisingly, that branch banks tend to fail faster. This is again contrary to previous work.

It is difficult, however, to both test significance and control for other bank characteristics with Kaplan-Meier survival functions. A series of regressions that used the survival time of the observation as the dependent variable are undertaken. Results are reported using a time ratio. 13

There are three ways mergers could be treated using duration analysis. Banks that merge with other banks could be dropped from the sample, following the procedure used by Cherin and Melicher (1988). Banks bought by other banks could be treated as failures because they may not have been "economically fit" enough to survive. This would follow Alhedeff and Alhedeff (1976). A third alternative is to censor the observation when it merges with another bank. This

\footnotetext{
${ }^{13}$ A time ratio indicates the fraction of the baseline time that an observation with one unit of the independent variable is expected to last. For instance, if the coefficient on new bank is 0.75 , then being a new bank decreases the expected survival time to $75 \%$ of non-new bank. A time ratio less than one indicates that the explanatory variable decreases survival time.
} 
option treats a merger as leaving the sample for a reason unrelated to solvency. It is mathematically equivalent to treating mergers and insolvencies as different types of failures and only estimating the effects of the independent variables on insolvency (Cox \& Oakes, 1984).

Results using different treatments of mergers are reported in Table 4. They are again at odds with the conventional wisdom, which predicts that branch banks would take longer to fail than unit banks. The results here indicate that branch banks fail faster than unit banks. The point estimates for outside branching banks indicate that outside branching banks survived somewhere between $79 \%$ (mergers fail) and 65\% (mergers censored) as long as unit banks. The point estimate for home branching banks indicates that they survive only two-thirds as long as unit banks.

The treatment of mergers affects the significance of several variables, including, amount of assets, number of firms in the county, and the key variable, outside branching. The issue of which treatment method is most appropriate will be returned to below.

The effects of other variables are as predicted. Being a new bank, having a large share of assets in loans, and having a large share of loans rediscounted decreases the expected time until the bank fails. Being larger increases the expected time until failure. Other than the striking finding regarding branching, the results are similar to the results of previous work. The impact of asset size matches the results of Calomiris and Mason (1997). The ratios of securities to assets, loans to assets, and rediscounts to assets, all match White (1984).

\section{How should mergers be treated?}

In the results reported above, the treatment of mergers affects the significance of the coefficient on branching. 1.5 Here the relative merits of the three different treatments are considered.

Most of the banks acquired during mergers were small unit banks in rural areas that merged with large banks that already had branches. The unit banks were located in places where the branch banks did not yet have an office. Since the banks that merge were not selected at

\footnotetext{
${ }^{14}$ After the first draft of this paper was completed, I discovered a working paper by Calomiris and Mason (2000) that, using a different data set, notes a similar effect.

${ }^{15}$ In tests focusing on California and using information on each banks assets updated yearly, branching is found to have a negative affect on survival regardless of how mergers are treated.
} 
random, dropping them from the sample may bias the results and would not be an appropriate treatment. 16

Mergers should also not be considered failures for two reasons. First, there are statistical differences between banks that merged and banks that failed. I test whether the survival time of mergers more closely resembles banks that failed or banks that survived. ${ }^{17}$ I estimate the effects of the independent variables on the length of survival for all non-merging banks (this is exactly the regression in Table 4, Column 1). With the estimates of the effects of the independent variables, I calculate the average expected survival time for failing banks, surviving banks, and merging banks. I find that the average expected time until failure for merging banks is longer than that for failed banks, though shorter than that for surviving banks. This suggests that merged banks are different than failures.

Second, the actions of bank supervisors suggest differences between merges and failures. The annual reports of the Bank Commissioner of Maryland list banks intending to merge and banks being placed in receivership in different places. ${ }^{18}$ If mergers were simply failures that were purchased by other banks rather than liquidated, then one would expect that banks would have started on the receiverships list and moved to the merger list. Instead the opposite occurred. Several banks started on the merger list but were later transferred to the receiver list. This is interpreted to mean that the merger would have proceeded if the bank to be purchased been solvent, but the merger was canceled and the bank closed by the state once it was found to be insolvent. This is evidence that banks that successfully merged with other banks were not failures. The appropriate treatment then is to censor the survival spell of the merged bank on the day it merged.

\section{Robustness of the Results}

These findings differ strikingly from the conventional wisdom. Several tests were therefore undertaken to check the robustness of the results. In all these tests, the higher failure rate of branch banks persists.

\footnotetext{
${ }^{16}$ The direction of the bias depends on whether the merged banks were failing or non-failing institutions. If these banks were non-failing then dropping them from the sample biases the results against finding a negative effect from branching.

${ }^{17}$ This is similar to an exercise conducted by Calomiris and Mason (1997).

${ }^{18}$ The introduction to each report summarizes events of the past year. One section lists consolidations and mergers, another voluntary liquidations, and a third banks in receivership.
} 


\section{Alternative Measures of Branching}

In the tests reported above, a dummy that indicates simply whether or not the bank has outside branches is used. Here, three alternatives measures are considered. The first splits the single dummy into two dummies: one for fewer than four branches and one for four or more branches. This specification captures the benefits to branching if the benefits occur only once the bank has several branches. One difficulty with this measure is that only eleven banks have four or more branches; thus an insignificant result may be due to a small effect or a small sample.

The second measure is the log of the number of cities in which the bank has branches. This measure tests whether the benefits to branching increase with the number of branches.

The third measure is the average distance from the bank's home office to its branches. This measure tests whether increased geographic dispersion better enabled banks to survive the Depression.

The results of the tests (Table 5) consistently find no increase in the duration of survival from being a branch bank. Having three or fewer branches has a significant detrimental effect on survival while having four or more branches has an insignificant effect. (The reasons for these differences are uncertain.) Tests using the log of the number of cities in which the bank had branches indicate that banks with branches in more cities fared worse.

Geographic diversification also appears to have yielded little benefit. A higher average distance to a bank's branches reduces expected survival time. The coefficient on the average distance suggests that for each extra mile of distance the bank survives $99 \%$ as long as a bank with one less mile of average distance. For the mean branch bank, the average distance to a branch is 17.5 miles, implying that such a branch bank survives $86 \%$ as long as a unit bank.

\section{Results by State}

The three states in the sample had different experiences both prior to and during the Depression. It is important to check whether the results are consistent across states.

Banks in California, had always been permitted to establish branches. While the number of branches was limited until 1921, many banks had experience managing branches. By 1929, California had the most extensive branch network in the United States. Maryland has the smallest number (12) of failures during the sample period. Most banks of the banks in Maryland that failed during the Depression were closed during the National Banking Holiday, which is

\footnotetext{
${ }^{19}$ I also use the inverse of the number of branches, which tests the same principle, and uncover similar findings.
} 
after the end of this study. The financial system in North Carolina was strongly affected by the failure of Caldwell and Company, a large Tennessee banking establishment. This shock caused the failure of many banks in North Carolina but did not affect the other states.

Table 6 presents the duration test results for each state. The negative effect of branching is significant in California and North Carolina and has approximately the same effect. It is worth noting that the negative effect of branching is the most strongly significant in California, where the branch network was the most extensive. Most of the other variables (except the ratio of total securities to assets) have similar effects in all three states. These results suggest that the effects of branching are not being distorted by combining the three states.

\section{Multi-Year Analysis of California}

Duration analysis allows data for individuals in the sample to be updated over the analysis period. As a check on the robustness of the results, information on banks in California is updated using the 1930, 1931, and 1932 annual reports. The results (Table 7) indicate even more negative effects from branching than in the non-updated analysis. In fact in this analysis branching reduces expected survival time regardless of how mergers are treated (results available from author).

\section{Effect of Size}

Branch banks tend to be larger than unit banks. 20 Separating the effects of size and branching indicates that being larger increases expected survival time while branching decreases expected survival time. If, however, branching allows banks to grow, then separating the two measures may hide the true benefit of branching. Removing log assets from the specification allows the opportunities to increase size from branching to be included in the total impact of branching. The results (Table 8) indicate that, even accounting for the growth opportunities from branching, branch banks still have a significantly shorter survival time.

\section{Distribution of Failures}

One factor that can affect the results of duration analysis is the choice of the way failures are distributed. The above analysis employs the log-logistic distribution. Using other distributions such as the Weibull, log-normal, gamma, and distribution free Cox-proportional

\footnotetext{
${ }^{20}$ While branch banks are larger, the exact relationship between size and branching is uncertain. The correlation between the log of total assets of the bank and the number of cities in which it has branches is 0.33 . Of the ten largest banks in California, Maryland, and North Carolina, the number of these that had branches outside the home office city was 4,2 , and 6 respectively.
} 
hazard yields results of similar magnitude and significance for all these distributions. A likelihood ratio test suggests that the log-logistic distribution provides the best fit.

\section{Inadequate Explanations}

Several potential explanations for these results can be readily rejected.

\section{Insufficient Geographic Distribution}

The first explanation is that banks in this sample may not have enough branches to benefit from diversification. It may take a substantial number of branches to effectively diversify geographically. With insufficient diversification, one would not expect to find that branch banks were better survivors.

Under this line of reasoning, one would expect to find no effect. Instead, a significant negative impact to branching is found. This indicates that branch banks are distinct and different. Insufficient diversification is not a sufficient explanation. Also the results from Table 5 Column 4, using average distance to branches, indicate no benefit to increased geographic distribution. Over-Extension

Another explanation is that branch banks may have overextended themselves and failed when expected returns were not realized. During the Roaring 20's banks may have found it profitable to expand and take over other banks. The fact that the Depression of the 1930's was so prolonged may have made these expansions unprofitable causing the expanding banks to fail.

This hypothesis can be tested by examining the growth of assets and branches since 1924. ${ }^{21}$ Information on the assets and branches of banks is collected from the 1924 annual reports. A variety of measures, percent change in assets, percent changes in branches, or a dummy for switching from being a unit bank to a branch bank, are included in the regression analysis; none of the included measures change the effect of branching or affect survival in general (Table 9). Thus no evidence is found to support this explanation.

\section{A Potential Explanation}

Here a model is presented that uses diversification, risk, and return to explain the failure of branch banks. After the model is presented in depth, several predictions are tested. The data corroborates these predictions.

\footnotetext{
${ }^{21}$ Note that this requires that banks less than five years old must be excluded from the analysis.
} 


\section{A. The Model}

The argument, that geographic diversification makes branch banks less risky, assumes that branch banks hold the same portfolios as unit banks. This may not have been the case. Branch banks may have believed that they were more diversified. That belief may have led them to hold riskier portfolios in order to earn higher returns and still have the same level of overall risk as unit banks. As long as shocks were idiosyncratic, this would have been the case, but if shocks were largely systematic, as they may have been in the Depression, then branch banks with riskier portfolios would have been more likely to fail.

I hypothesize, following Miron (1986), that one of the important ways that banks benefited from branching was through reduced volatility of their liabilities. Withdrawals in one location would have been offset by deposits in another location. So that branch banks would not have had to hold as many reserves (cash or securities easily converted into cash) to meet depositor demand. The bank could simply shuttle funds between branches. Thus, branch banks could have extended more loans, and earned higher profits. This strategy would have been effective as long as withdrawals were relatively uncorrelated across branches, or idiosyncratic. If, however, deposit withdrawals occurred at all branches at the same time, a systemic withdrawal, branch banks with fewer reserves, would have been unable to meet withdrawal demand and have been forced to liquidate loans or suspend operations.

From the perspective of a unit bank, an idiosyncratic withdrawal was the same as a systemic withdrawal. Both affect all the offices of the bank, so more reserves would have been held to meet withdrawals than at a branch bank. Because unit banks held more reserves, they would not have been as affected by shifts in depositor behavior.

In this explanation of branch bank failure rates, the Great Depression was a time when deposit withdrawals shifted from idiosyncratic to systemic. During the 1920's, there was less concern about the overall financial health of banks compared to the 1930's where there was great concern about financial instability (Temin 1976; Coe 1999). One way this financial instability manifested itself was in the city, regional, and national bank panics (Wicker 1996). During bank panics depositors would run the banks and withdraw their funds from the banks. Bank runs are thus a perfect example of a systemic deposit withdrawal. Unit banks, with more reserves, would have been better able to deal with these systemic shocks. Branch banks, with fewer reserves, would have been more likely to be unable to meet withdrawal demand and forced to liquidate 
loans. Liquidating loans would have put further pressure on banks already suffering from decreased asset values. Thus during the Great Depression, and especially during bank runs, branch banks would have been more likely to fail.

The main points of the model can be illustrated more formally. For each bank let (n) be the number of branches and let (D) be the deposits in a particular branch. This assumes that deposits are the same size in all branches. Relaxing this assumption complicates the analysis, but does not change the results. The bank can make loans with the deposits or it can hold them in reserve against withdrawals. Let $(\gamma)$ be the share of assets held in reserve. Loans pay a return (r) while reserves pay no return. If the bank does not hold sufficient reserves to meet deposit withdrawals then it must liquidate loans. Loans are liquidated at a loss and the bank receives only fraction $(\beta)$ of the par value. Each branch may experience net deposit inflows or outflows. For simplicity the size of these inflows are presumed to be the same across branches, though again relaxing this assumption only complicates the model without changing the qualitative results. If net outflows occur, they are assumed to be fraction $(\alpha)$ of deposits. Net outflows occur with probability (p). If net inflows occur, they are assumed to be fraction $(\varepsilon)$ of deposits. Net inflows occur with probability (1-p).

Certain constraints are placed on the variables so that they make economic sense. The rate of return is assumed to be greater than zero. Deposits are assumed to be positive. The number of branches is any counting number (where one branch implies a unit bank). All other variables are constrained to be between zero and one. To ensure that the bank wishes to avoid liquidating loans, the quantity $(1 / \beta)$ is assumed to be greater than $(1+r)$. No constraints are put on the size of $\varepsilon$ relative to $\alpha$.

The only choice variable for the bank is the share of deposits that it will devote to reserves versus loans. The bank chooses $\gamma$ to maximize profits, subject to the constraint that it is solvent in expectation. The solvency constraint requires the bank to be concerned with whether net outflows will occur at the end of the period. The size of net deposits, from the perspective of the entire bank, depends on the correlation of inflows and outflows across branches. For branch banks the choice of $\gamma$ will be examined for the case where net deposits are perfectly correlated across branches and where net deposits have no correlation across branches. Unit banks, with one branch, automatically have perfect correlation across branches. 
If deposits are perfectly correlated across branches, there will be either net outflows of deposits from every branch, or there will be net inflows into every branch. The bank will hold reserves to protect itself against the case where an outflow occurs. In this situation, unit and branch banks carry out the following maximization:

$$
\max _{\gamma} \gamma \mathrm{Dn}+(1-\gamma) \operatorname{Dn}(1+r)-\mathrm{Dn}
$$

subject to the constraint that

$$
\gamma \mathrm{Dn}+(1-\mathrm{p})[(1-\gamma) \operatorname{Dn}(1+\mathrm{r})+\mathrm{Dn} \varepsilon]+\mathrm{p}[(1-\gamma) \operatorname{Dn}-((\alpha-\gamma) / \beta) \operatorname{Dn}](1+\mathrm{r}) \geq \mathrm{Dn}+(1-\mathrm{p}) \operatorname{Dn} \varepsilon-\mathrm{pDn} \alpha
$$

Carrying out the maximization gives the following (where pc stands for perfect correlation):

$$
\gamma_{p c}=\frac{p \alpha+p \alpha r-\beta r-p \alpha \beta}{p+p r-\beta r}
$$

Mathematically this solution is not necessarily constrained to lie between zero and one. The economically constrained solution is then that the bank sets $\gamma=0$, when the values of $p, \alpha, r$, and $\beta$ would mathematically produce a solution where $\gamma<0, \gamma$ equals the above solution when it lies between zero and one, and $\gamma=1$ when the values of $p, \alpha, r$, and $\beta$ would produce a solution where $\gamma>1$. The solution for $\gamma$ is independent of the number of branches; thus both unit banks and branch banks will choose to hold the same portion of deposits as reserves.

If deposits are not correlated across branches then deposit outflows at some branches will be offset by deposit inflows at other branches. Reserves cover the difference in these flows, rather than the entire outflow. Branch banks carry out the same maximization as before, subject to a slightly different constraint. In fact the constraint can take two forms. If expected inflows exceed expected outflows (Dne(1-p)>Dn $\alpha$ ), the bank trivially sets $\gamma$ equal to zero. If expected deposit inflows are less then expected outflows $(\operatorname{Dn} \varepsilon(1-p)<D n \alpha p)$ then the branch bank will need to hold some reserves and will carry out the following maximization.

$$
\max _{\gamma} \gamma \mathrm{Dn}+(1-\gamma) \operatorname{Dn}(1+\mathrm{r})-\mathrm{Dn}
$$

subject to the constraint that

$$
\gamma \operatorname{Dn}+(1-\gamma) \operatorname{Dn}(1+\mathrm{r})+\mathrm{p}[(1-\gamma) \operatorname{Dn}-((\alpha-\gamma) / \beta) \operatorname{Dn}](1+\mathrm{r}) \geq \operatorname{Dn}+(1-\mathrm{p}) \operatorname{Dn} \varepsilon-\mathrm{pDn} \alpha
$$

Solving the above maximization problem gives (where nc stands for no correlation):

$$
\gamma_{\mathrm{nc}}=\frac{\mathrm{p} \varepsilon+\mathrm{pr} \varepsilon+\mathrm{p} \alpha+\mathrm{pr} \alpha+\beta \varepsilon-\mathrm{p} \beta \varepsilon-\mathrm{p} \beta \alpha-\mathrm{r} \beta-\varepsilon-\mathrm{r} \varepsilon}{1+\mathrm{r}-\mathrm{r} \beta}
$$


Again the solution is not mathematically constrained to lie between zero and one. If the values of $\mathrm{p}, \alpha, \mathrm{r}, \varepsilon$, and $\beta$ suggest a solution where $\gamma<0$, the bank sets $\gamma=0$ and if $\mathrm{p}, \alpha, \mathrm{r}, \varepsilon$, and $\beta$ suggest a solution where $\gamma>0$, the bank sets $\gamma=1$. Again the solution does not involve the number of branches the bank has, although in order for the maximization to apply, the bank must have at least two offices.

It can be shown that $\gamma_{\mathrm{pc}} \geq \gamma_{\mathrm{nc}}$ and that as long as both shares are not at the same boundary $\left(\gamma_{\mathrm{pc}}>0\right.$ and $\left.\gamma_{\mathrm{nc}}<1\right)$, then $\gamma_{\mathrm{pc}}>\gamma_{\mathrm{nc}}$ (proof available from author). The implications are clear. Branch banks will hold fewer reserves than unit banks if deposits are uncorrelated. In fact, if withdrawals are even slightly less than perfectly correlated, then branch banks will hold fewer reserves than unit banks. The lower the correlation, the greater the difference in reserves.

If the runs of the Great Depression marked a shift from low to high correlation in deposit outflows, then the model suggests that branch banks would have been less likely than unit banks to have held reserves sufficient to meet demand. Without sufficient reserves, branch banks would have had to liquidate loans. If banks were unable to get the book value for these loans, it would have pushed them closer to insolvency.

The model does not claim that deposit-reserves differences were the only differences in the portfolios of unit and branch banks. It may well be that branch banks were willing to hold loans that were less liquid or loans with a higher risk level. It is, however, not possible to test these portfolio choices with the data currently available, while it is possible to test whether branch banks held fewer reserves to deposits.

\section{B. Testing the Model}

The explanation described above generates several testable hypotheses. The first is that compared to unit banks, branch banks should have more deposits relative to liquid reserves. Second, branch banks should be more likely to fail during bank runs.

\section{Portfolio Choices of Branch Banks}

The model presented above suggests that banks that reduced the volatility of their liabilities would hold fewer reserves against deposits. This is a testable proposition.

I regress the reserves to demand deposits ratio (where reserves are the sum of cash, securities, due from banks, and the Federal Reserve and subtracting due to banks), on branch bank dummies, the size of the bank, other bank portfolio choices, and various location 
characteristics. ${ }^{22}$ The rationale above suggests that the branch banks should hold fewer reserves to demand deposits. This is exactly what is found (see Table 10). 2.3

\section{Timing of Closures}

A second prediction of the model is that branch banks would be especially vulnerable to runs. The Kaplan-Meier Survival Analysis, from Figure 1, suggests that branch banks tended to fail in clusters, which is suggestive of bank runs. The historical record further supports this idea. The failure clusters occured in late 1930, late 1931, and early 1933, periods in which bank runs have been identified (Friedman \& Schwartz 1963; Wicker 1996).

The first cluster of failures was during the banking crises of late 1930. Wicker (1996) attributes the bank failures of this period to the failure of Caldwell \& Company, a bank located in Tennessee, and its banking network. Consistent with Wicker's hypothesis, the bank failures in the sample occur in North Carolina, a state that had several banks that were closely associated with Caldwell. Wicker reports that many banks were subjected to runs as depositors learned about possible associations with Caldwell.

A second cluster of bank failures occurred during December 1931 and January 1932 in both North Carolina and California. Friedman \& Schwartz (1963) and Wicker (1996) described a nationwide crisis in September and October of 1931 but write that it had concluded by November. Newspapers are examined to determine if a local run had occurred. Since all the failures in California occurred in Los Angeles or Orange County, The Los Angeles Times is consulted. Short articles were written about the bank closings during the period in question. A panic was not mentioned; however, this period is the only time from 1930 to 1934 that The Times devoted attention to bank closings in California. This may indicate that December 1931January 1932 was a time when the public was especially interested in bank health. The

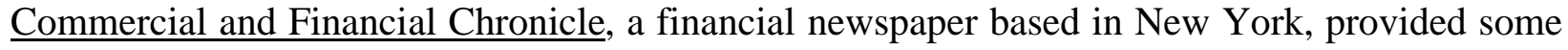
coverage of the bank closings in North Carolina. It reported several bank runs during December \& January, including one where the National Credit Corporation stepped in to prevent the closing of one of North Carolina's largest banks.

\footnotetext{
${ }^{22}$ Securities are included in reserves, so the ratio of securities to reserves is not included in the regression. The more a single crop dominates the local agricultural sector, the less a bank could smooth its withdrawals during harvest season. Thus, an agricultural diversity index is included.

${ }^{23}$ Demsetz and Strahan (1995) and Hughes, Lang, Mester, and Moon (1996) find similar portfolio shifting behavior for large banks in the late 1980's.
} 
The third cluster occurred just prior to the national banking holiday declared by President Roosevelt in 1933. There are two reasons why there would be high failure rates at this time. The first was due to bank runs. Friedman and Schwartz (1963) describe how bank runs occurred as concern spread that individual state governments were preparing to declare bank holidays. The second reason is due to the way failure dates are determined. Many banks did not reopen after the National Bank Holiday. All these banks were assigned the start of their state's banking holiday as the date of failure because it was the official day of closure. These two reasons create a large group of banks that failed due to both runs and solvency concerns. 24

\section{Reasons for Failure}

The reasons that banks were closed also indicate that bank runs may have played a role in branch bank failure. The Report of the Superintendent of Banks for California for 1978 published the reasons for the suspension of each state bank since the creation of the Office of the Superintendent. ${ }^{25}$ There were eight reasons why a bank might have been shut down. The reasons are: Mismanagement, Dishonesty of Officer or Employee, Frozen assets, Local or General Depression, Adversely affected by the failure of another bank, Excessive overhead, Heavy Cash Withdrawal, and Bond Depreciation. A bank could be closed for more than one reason. Table 11 lists the number of failures of home branching, outside branching, and unit banks, as well as the number of times a reason was given for closing a bank within each group. Most reasons for the failure of branch and unit banks occur evenly. The important exception is heavy cash withdrawal. Just under half of the unit banks are closed due to heavy deposit withdrawal, while all the branch banks have heavy deposit withdrawal as a reason for suspension. 26

\section{Impact of a Portfolio Measure on the Negative Effect of Branching}

The model predicts that it is not branching itself that produces a high failure rate, but rather the portfolio choices encouraged by branching. If this is correct, then incorporating information about portfolio choice into the regression models used earlier should reduce, if not eliminate, the negative effects of have an outside branch.

\footnotetext{
${ }^{24}$ It should be noted that these banks are failures in the Kaplan-Meyer analysis, but not in the regression analysis above, because the sample period ends before the National Bank Holiday. Extending the sample period to include these banks does not affect the results.

${ }^{25}$ This list includes banks that suspended as well as those that failed. During the sample period, 43 banks were closed, only two of these reopened. The analysis is restricted to banks that failed.

${ }^{26}$ The 1931-1932 Annual Report for California notes that the major cause of failure during that year was Heavy Cash Withdrawal. This may be further evidence of a minor bank panic during December 1931 and January 1932.
} 
The model suggests that two pieces of information must be taken into account. The first is the choice of deposits backed by reserves. This measure is constructed by regressing the reserve-demand deposit ratio on other bank portfolio and location characteristics. ${ }^{27}$ This regression is similar to the one demonstrating that branch banks hold a different portfolio only the branch bank dummies have been removed. The residual from this regression is captured and used as a measure of excess of insufficient reserves to deposits. Having a negative residual indicates that the bank is holding fewer reserves to back demand deposits than its other characteristics would predict. The more negative the residual the fewer reserves the bank holds relative to deposits thus measuring how much risk the bank is taking with its choice of reserves to support deposits. Since branch banks held fewer reserves per dollar of demand deposits, removing the branch bank dummies makes branch banks more likely to have negative residuals in this new regression.

The analytical model developed above suggests that holding fewer reserves will cause the bank to fail, but only when subjected to a bank run. Thus, information about whether the bank was subject to a run must also be included. The reasons for bank failure in California provide information on banks that closed during a bank run, but they do not provide information on banks that experienced a run but did not close. ${ }^{28}$ Most of the banks that failed due to heavy cash withdrawals were closely preceded by the failure of a nearby bank, so the failure of a nearby bank is used as an indicator that the bank is exposed to a run. I consider a bank to be exposed to a bank run for 10 days after there is a bank failure within 50 miles of the bank's home office. This measure captures both banks that failed and banks that survived a bank run. Thus, the two measures for lower and upper bounds on bank runs. Using "heavy cash withdrawal" assumes that each bank that was subjected to a run was closed, while using the geographic/timing indicator assumes that all banks near a bank failure were the subject of bank runs. The truth is likely somewhere between the two measures.

In order to use the variable based on heavy cash withdrawal, and be able to compare the results to the other regressions carried out in this particular test, the sample is restricted to banks from California. ${ }^{29}$ The base regression is the same one reported in Table 4 . The regressions

\footnotetext{
${ }^{27}$ Reserves again is the sum of cash, securities, due from banks, due from the Federal Reserve minus due to banks.

${ }^{28}$ One of the banks that was closed temporarily lists heavy cash withdrawals as a reason fro closure.

${ }^{29}$ This may be a cleaner test for other reasons. Failures resulting from the failure of Caldwell and Company involved systemic withdrawals for reasons more closely related to choice of associates than choice of portfolio.
} 
testing the model add the measure of deposits not backed by reserves, a bank run indicator, and their interaction. The model predicts that when these terms are included the negative affect of branching should disappear. The estimation results appear in Table 12.

The results are exactly as the model predicts. In the regressions without information deposits backed by reserves and runs, outside branching banks survive a significantly shorter period of time. When this information is included, the coefficient on outside branching banks is closer to one and insignificant. Also, as predicted by the model, having a fewer reserves relative to demand deposits, during a bank run, significantly decreases the time until failure.

The coefficient on outside branching is still less than one but is insignificant. This is not surprising. The measures included here account for only part of the banks' portfolios. If the banks were willing to hold less reserves against their liquid liabilities, then it is likely that they adjusted their other asset holdings as well, potentially by changing the risk level or maturity structure of their loans. The data do not allow measurement of these characteristics, but if they did, then including those measures is predicted to further decrease the negative effect of branch banking.

\section{Conclusion}

Previous studies based on cross-country or cross-state evidence (Wernette 1932; Wheelock 1995; Grossman 1994; Mitchner 2000) found that allowing branch banking reduced the rate of bank failure. This study finds that branch banks had a higher failure rate than unit banks. While it is not immediately clear how to reconcile these findings, there are some possibilities.

One explanation is that branch banks may help remove weak banks from the system, so that the system becomes stronger even though branch banks themselves may not be more resistant to shocks. Allowing bank to establish branches increases the level of competition by decreasing the costs to entering in a new market. ${ }^{30}$ This increased level of competition may have forced many marginally profitable banks to voluntarily liquidate or allow themselves to be purchased by other banks. The longer branching had been allowed, the fewer weak banks would have remained and the more stable the banking system as a whole would have become. Thus, by the time of the Depression, branch banking could have increased the stability of the banking

Rather than decide whether to treat these banks separately, and how to do so, it may be more reasonable to restrict the sample to California.

${ }^{30}$ Southworth (1928) suggests that administrative overhead was reduced. 
system of a country or state, producing the lower failure rates found in previous work, even though branch banks might not have had a lower failure rate than the remaining unit banks. More work will need to be done to test this conjecture.

While the conjecture stated above may or may not be correct, it does suggest that the findings in this paper should not necessarily lead to abandoning the belief that permitting branch banking increases financial stability. Rather this paper indicates that the relationship is more complex than is previously thought. 


\section{References:}

Alhadeff, David and Charlotte Alhadeff. "Growth and Survival Patterns of New Banks 19481970." Journal of Money, Credit, \& Banking 8 (1976), 199-208.

Bank Commissioner of the State of Maryland. Annual Report, Baltimore: Office of the Bank Commissioner, 1928-1934.

Benston, George, Robert Eisenbeis, Paul Horvitz, Edward Kane, \& George Kaufman. Perspectives on Safe and Sound Banking; Past, Present and Future, Cambridge, Massachusetts: MIT Press Edition, 1986.

Bordo, Michael. "Some Historical Evidence 1870-1933 on the Impact and International Transmission of Financial Crises." NBER Working Paper 1606 (1985).

Calomiris, Charles \& Joseph Mason. "Contagion and Bank Failures During the Great Depression: The June 1932 Chicago Banking Panic." American Economic Review. 87 (1997), 863-83.

Calomiris, Charles \& Joseph Mason. "Causes of U.S Bank Distress During the Depression." NBER Working Paper 7919, (2000).

Cherin, Antony \& Ronald Melicher. "Impact of Branch Banking on Bank Firm Risk via Geographic Market Diversification.” Quarterly Journal of Business and Economics 27(2) (Spring 1988), 73-95.

Coe, Patrick. "Financial Crises and the Great Depression: A Regime Switching Approach." unpublished manuscript, University of Calgary, Calgary (1999).

Commercial and Financial Chronicle, New York, New York, various issues, December 1931February 1932.

Cox, D.R. \& D. Oakes. Analysis of Survival Data, London: Chapman and Hall, 1984.

Demsetz, Rebecca and Philip Strahan. "Historical Patterns and Recent Changes in the Relationship between Bank Holding Company Size and Risk." Economic Policy Review Federal Reserve Board of New York, (1995), 13-26.

Department of the North Carolina Corporation Commission. Reports of the Condition of State Banks, Raleigh: Office of the Commission, 1928-1934.

Friedman, Milton and Anna Schwartz. A Monetary History of the United States, 1867-1960, Princeton: Princeton University Press, 1963.

Gart, Alan. Regulation, Deregulation, Reregulation, New York: John Wiley and Sons, Inc., 1994. 
Grossman, Richard. “The Shoe That Didn't Drop: Explaining Banking Stability in the Great Depression.” Journal of Economic History 54(3) (1994) 654-682.

Hughes, Joseph, Willaon Lang, Loretta Mester, and Choon-Geol Moon. "Efficient Banking Under Interstate Branching” Journal of Money Credit and Banking 28:4 (1996) 1045-1071.

Kalbfleisch, J.D. and R.L. Prentice. The Statistical Analysis of Failure Time Data, New York, New York: John Wiley and Sons, 1980.

The Los Angeles Times, Los Angeles, California, various issues, January 1930-December 1933.

Miron, Jeffery. "Financial Panics, the Seasonality of the Nominal Interest Rate, and the Founding of the Fed." American Economic Review 76 (1986), 125-140.

Mitchner, Kris "Do Supervision and Regualtion Prevent Bank Failures? Evidence from the Great Depression." unpublished manuscript, University of California, Berkeley (2000).

Preston, Howard. "Recent Developments in Branch Banking." American Economic Review 14 (1928), 443-462.

Southworth, Shirley Donald. Branch Banking in the United States, New York, New York: McGraw-Hill Book Company, 1928.

Superintendent of Banks of the State of California. Annual Report, Sacramento: California State Printing Office, 1929-1934.

Temin, Peter. Did Monetary Forces Cause the Great Depression, Toronto, Ontario: W. W. Norton \& Company, 1976.

Wernette, John. "Branch Banking in California and Bank Failures.” The Quarterly Journal of Economics 46(2) (1932), 362-365.

Wheelock, David. "Regulation and Bank Failures: New Evidence from the Agricultural Collapse of the 1920's." Journal of Economic History 52(4) (1992) 806-825.

Wheelock, David. "Regulation, Market Structure, and the Bank Failures of the Great Depression." Federal Reserve Bank of St. Louis Review 77(2) (March/April 1995) 27-38.

White, Eugene. "A Reinterpretation of the Banking Crises of 1930." Journal of Economic History 44(1) (1984), 119-138.

Wicker, Elmus. The Banking Panics of the Great Depression, New York, New York: Cambridge University Press, 1996. . 
Winton, Andrew. "Don't Put All Your Eggs in One Basket? Diversification and Specialization in Lending," Institute for Financial Studies Working Paper 9903, University of Minnesota, Carlson School of Management (1999). 
Table 1

Numbers of Banks with Outside Branches

\begin{tabular}{|c|c|c|c|c|}
\hline $\begin{array}{c}\text { Outside } \\
\text { Branches }\end{array}$ & All States & California & Maryland & North Carolina \\
\hline 0 & 590 & 155 & 128 & 307 \\
\hline 1 & 43 & 15 & 3 & 25 \\
\hline 2 & 10 & 5 & 2 & 3 \\
\hline 3 & 10 & 5 & & 3 \\
\hline 4 & 3 & 1 & & 1 \\
\hline 5 & 3 & & & 1 \\
\hline 6 & 1 & 1 & & \\
\hline 17 & 1 & 1 & & \\
\hline 20 & 1 & 1 & & \\
\hline 34 & 1 & & & \\
\hline 88 & & & & \\
\hline
\end{tabular}

Table 2

Descriptive Statistics by Branch Type

\begin{tabular}{|l|c|c|c|}
\hline & Unit & $\begin{array}{c}\text { Outside } \\
\text { Branching }\end{array}$ & $\begin{array}{c}\text { Home } \\
\text { Branching }\end{array}$ \\
\hline Number & 566 & 73 & 25 \\
\hline Mean Assets (dollars) & $1,004,000$ & $14,400,000$ & $26,300,000$ \\
\hline Median Assets (dollars) & 400,000 & $1,870,000$ & $8,730,000$ \\
\hline Mean Age (years) & 18 & 21 & 27 \\
\hline Mean Net Worth-Asset Ratio & 0.16 & 0.13 & 0.12 \\
\hline Mean Securities-Asset Ratio & 0.15 & 0.16 & 0.25 \\
\hline Mean Loan-Asset Ratio & 0.60 & 0.63 & 0.55 \\
\hline & & & 17 \\
\hline Number Surviving & 394 & 44 & 5 \\
\hline Number Failing & 117 & 26 & 3 \\
\hline Number Merging & 55 & 3 & \\
\hline
\end{tabular}


Table 3

Logit Analysis with Outside Branch Banks as a Single Group

Dependent Variable: Indicator of survival until March 1, 1933

\begin{tabular}{|c|c|c|c|c|}
\hline & \multicolumn{2}{|c|}{ Drop Mergers } & \multicolumn{2}{|c|}{ Mergers Fail } \\
\hline $\begin{array}{l}\text { Branch Outside } \\
\text { Home City }\end{array}$ & $\begin{array}{l}-0.372 \\
(0.28)\end{array}$ & $\begin{array}{c}-0.803 * * \\
(0.33)\end{array}$ & $\begin{array}{l}-0.094 \\
(0.27)\end{array}$ & $\begin{array}{c}-0.410 \\
(0.31)\end{array}$ \\
\hline $\begin{array}{l}\text { Branch in Home } \\
\text { City Only }\end{array}$ & $\begin{array}{l}-0.548 \\
(0.58)\end{array}$ & $\begin{array}{r}-0.967 \\
(0.64)\end{array}$ & $\begin{array}{l}-0.494 \\
(0.49)\end{array}$ & $\begin{array}{l}-0.790 \\
(0.54)\end{array}$ \\
\hline $\begin{array}{l}\text { Fraction Population } \\
\text { in Urban Areas }\end{array}$ & & $\begin{array}{l}-0.253 \\
(0.49)\end{array}$ & & $\begin{array}{c}-0.379 \\
(0.44)\end{array}$ \\
\hline $\begin{array}{l}\text { Number of Firms } \\
\text { the in County }\end{array}$ & & $\begin{array}{c}-0.178 * \\
(0.10)\end{array}$ & & $\begin{array}{c}-0.159 * \\
(0.09)\end{array}$ \\
\hline New Bank & & $\begin{array}{l}-0.614 \\
(0.37) \\
\end{array}$ & & $\begin{array}{c}-0.588 * \\
(0.33)\end{array}$ \\
\hline $\begin{array}{l}\text { Log Assets } \\
\text { (in } \$ 10,000)\end{array}$ & & $\begin{array}{c}0.317 * * * \\
(0.11)\end{array}$ & & $\begin{array}{c}0.227 * * \\
(0.10)\end{array}$ \\
\hline Loans to Assets & & $\begin{array}{c}-1.896^{*} \\
(1.02)\end{array}$ & & $\begin{array}{l}-1.153 \\
(0.93)\end{array}$ \\
\hline $\begin{array}{l}\text { Total Securities to } \\
\text { Assets }\end{array}$ & & $\begin{array}{c}-0.764 \\
(0.1 .34) \\
\end{array}$ & & $\begin{array}{l}-0.555 \\
(1.16) \\
\end{array}$ \\
\hline Net Worth to Assets & & $\begin{array}{l}-0.327 \\
(1.32) \\
\end{array}$ & & $\begin{array}{l}-0.107 \\
(1.22) \\
\end{array}$ \\
\hline $\begin{array}{l}\text { Rediscounts to } \\
\text { Assets }\end{array}$ & & $\begin{array}{l}-3.530 \\
(2.41) \\
\end{array}$ & & $\begin{array}{c}-4.500^{*} \\
(2.31)\end{array}$ \\
\hline Commercial Bank & $\begin{array}{l}0.165 \\
(0.25)\end{array}$ & $\begin{array}{l}0.324 \\
(0.28)\end{array}$ & $\begin{array}{l}0.244 \\
(0.24)\end{array}$ & $\begin{array}{l}0.338 \\
(0.25)\end{array}$ \\
\hline $\begin{array}{l}\text { Commercial, } \\
\text { Savings \& Trust }\end{array}$ & $\begin{array}{l}0.391 \\
(0.42)\end{array}$ & $\begin{array}{l}0.017 \\
(0.47)\end{array}$ & $\begin{array}{l}0.274 \\
(0.36)\end{array}$ & $\begin{array}{c}0.033 \\
(0.406)\end{array}$ \\
\hline Maryland & $\begin{array}{c}1.243 * * * \\
(0.36)\end{array}$ & $\begin{array}{c}0.814^{*} \\
(0.42)\end{array}$ & $\begin{array}{c}1.251 * * * \\
(0.30)\end{array}$ & $\begin{array}{c}0.855 * * \\
(0.34)\end{array}$ \\
\hline North Carolina & $\begin{array}{c}-0.723 * * * \\
(0.22)\end{array}$ & $\begin{array}{c}-0.849 * * \\
(0.38)\end{array}$ & $\begin{array}{c}-0.510 * * * \\
(0.20)\end{array}$ & $\begin{array}{c}-0.768 * * \\
(0.33)\end{array}$ \\
\hline Constant & $\begin{array}{c}1.066^{* * * *} \\
(0.19)\end{array}$ & $\begin{array}{l}1.694 * \\
(1.03)\end{array}$ & $\begin{array}{c}0.589 * * * \\
(0.16)\end{array}$ & $\begin{array}{l}1.119 \\
(0.91)\end{array}$ \\
\hline Number Subjects & 603 & 590 & 664 & 651 \\
\hline Log Likelihood & -342.6 & -320.8 & -410.4 & -389.4 \\
\hline
\end{tabular}

Standard Errors in parentheses

* - indicates significant at $10 \%$ level

** - indicates significant at $5 \%$ level

*** - indicates significant at $1 \%$ level

Positive coefficient indicates that the variable increases likelihood of survival 
Table 4

Survival Analysis with Varying Treatments of Merged Banks

Dependent Variable: Time from June 30, 1929 until failure or March 1, 1933

\begin{tabular}{|c|c|c|c|}
\hline & Drop Mergers & Mergers Fail & Mergers Censored \\
\hline $\begin{array}{l}\text { Branch Outside } \\
\text { Home City }\end{array}$ & $\begin{array}{c}0.681 * * \\
(0.50-0.94) \\
\end{array}$ & $\begin{array}{c}0.786 \\
(0.56-1.11) \\
\end{array}$ & $\begin{array}{c}0.651 * * * \\
(0.48-0.89) \\
\end{array}$ \\
\hline $\begin{array}{l}\text { Branch in Home } \\
\text { City Only }\end{array}$ & $\begin{array}{c}0.628 \\
(0.33-1.19)\end{array}$ & $\begin{array}{c}0.716 \\
(0.38-1.34) \\
\end{array}$ & $\begin{array}{c}0.629 \\
(0.34-1.18)\end{array}$ \\
\hline $\begin{array}{l}\text { Fraction Population } \\
\text { in Urban Areas }\end{array}$ & $\begin{array}{c}0.845 \\
(0.52-1.36) \\
\end{array}$ & $\begin{array}{c}0.723 \\
(0.44-1.20) \\
\end{array}$ & $\begin{array}{c}0.834 \\
(0.52-1.33) \\
\end{array}$ \\
\hline $\begin{array}{l}\text { Number of Firms in } \\
\text { the County }\end{array}$ & $\begin{array}{c}0.919 * \\
(0.83-1.01)\end{array}$ & $\begin{array}{c}0.921 * \\
(0.83-1.02)\end{array}$ & $\begin{array}{c}0.925 \\
(0.84-1.02)\end{array}$ \\
\hline New Bank & $\begin{array}{c}0.717 * \\
(0.50-1.02)\end{array}$ & $\begin{array}{c}0.630 * * \\
(0.44-0.91)\end{array}$ & $\begin{array}{c}0.718 * \\
(0.51-1.02)\end{array}$ \\
\hline $\begin{array}{l}\text { Log Assets } \\
\text { (in } \$ 10,000)\end{array}$ & $\begin{array}{c}1.149 * * \\
(1.03-1.29)\end{array}$ & $\begin{array}{c}1.095^{*} \\
(0.98-1.23) \\
\end{array}$ & $\begin{array}{c}1.158 * * * \\
(1.04-1.29)\end{array}$ \\
\hline Loans to Assets & $\begin{array}{c}0.399 * \\
(0.15-1.08)\end{array}$ & $\begin{array}{c}0.557 \\
(0.19-1.60)\end{array}$ & $\begin{array}{c}0.388 * \\
(0.15-1.03)\end{array}$ \\
\hline $\begin{array}{l}\text { Total Securities to } \\
\text { Assets }\end{array}$ & $\begin{array}{c}0.722 \\
(0.20-2.67)\end{array}$ & $\begin{array}{c}0.816 \\
(0.21-3.10)\end{array}$ & $\begin{array}{c}0.662 \\
(0.18-2.39)\end{array}$ \\
\hline Net Worth to Assets & $\begin{array}{c}0.855 \\
(0.24-3.06)\end{array}$ & $\begin{array}{c}0.892 \\
(0.23-3.49)\end{array}$ & $\begin{array}{c}0.786 \\
(0.22-2.76)\end{array}$ \\
\hline $\begin{array}{l}\text { Rediscounts to } \\
\text { Assets }\end{array}$ & $\begin{array}{c}0.052 * * \\
(0.01-0.53)\end{array}$ & $\begin{array}{c}0.026 * * * \\
(0.00-0.33)\end{array}$ & $\begin{array}{c}0.064 * * \\
(0.01-0.61)\end{array}$ \\
\hline Commercial Bank & $\begin{array}{c}1.128 \\
(0.86-1.48)\end{array}$ & $\begin{array}{c}1.097 \\
(0.82-1.47) \\
\end{array}$ & $\begin{array}{c}1.093 \\
(0.84-1.43)\end{array}$ \\
\hline $\begin{array}{l}\text { Commercial, Savings } \\
\& \text { Trust }\end{array}$ & $\begin{array}{c}0.934 \\
(0.57-1.53) \\
\end{array}$ & $\begin{array}{c}0.919 \\
(0.56-1.50) \\
\end{array}$ & $\begin{array}{c}0.937 \\
(0.58-1.52) \\
\end{array}$ \\
\hline Maryland & $\begin{array}{c}1.430 \\
(0.93-2.20)\end{array}$ & $\begin{array}{c}1.603 * \\
(1.05-2.44)\end{array}$ & $\begin{array}{c}1.373 \\
(0.90-2.09)\end{array}$ \\
\hline North Carolina & $\begin{array}{c}0.570 * * * \\
(0.39-0.84) \\
\end{array}$ & $\begin{array}{c}0.558 * * * \\
(0.38-0.82) \\
\end{array}$ & $\begin{array}{c}0.569 * * * \\
(0.39-0.82)\end{array}$ \\
\hline Gamma & 0.526 & 0.623 & 0.521 \\
\hline Number Subjects & 589 & 650 & 650 \\
\hline Number Failures & 178 & 239 & 178 \\
\hline Log Likelihood & -427.1 & -580.8 & -434.6 \\
\hline
\end{tabular}

95\% confidence interval in parentheses

* - indicates significant at $10 \%$ level

$* *$ - indicates significant at $5 \%$ level

$* * *$ - indicates significant at $1 \%$ level 
Table 5

Survival Analysis with Varying Treatments of Branch Banks

Dependent Variable: Time from June 30, 1929 until failure or March 1, 1933

\begin{tabular}{|c|c|c|c|c|}
\hline & $\begin{array}{l}\text { Dummy } \\
\text { Indictor }\end{array}$ & $\begin{array}{l}\text { Multiple } \\
\text { Dummies }\end{array}$ & $\begin{array}{c}\text { Log of the } \\
\text { Number of } \\
\text { Outside Cities }\end{array}$ & $\begin{array}{c}\text { Average } \\
\text { Distance to a } \\
\text { Branch } \\
\end{array}$ \\
\hline $\begin{array}{l}\text { Branch Outside } \\
\text { City Only }\end{array}$ & $\begin{array}{l}0.651 * * * \\
(0.48-0.89)\end{array}$ & & & \\
\hline $\begin{array}{l}\text { Few Branch Outside } \\
\text { Home City }\end{array}$ & & $\begin{array}{c}0.650 * * * \\
(0.47-0.89)\end{array}$ & & \\
\hline $\begin{array}{l}\text { Many Branch Outside } \\
\text { Home City }\end{array}$ & & $\begin{array}{c}0.681 \\
(0.26-1.79)\end{array}$ & & \\
\hline $\begin{array}{l}\text { Log Number of Cities } \\
\text { with Branches }\end{array}$ & & & $\begin{array}{c}0.789^{*} \\
(0.60-1.04)\end{array}$ & \\
\hline $\begin{array}{l}\text { Average Distance to an } \\
\text { Outside Branch }\end{array}$ & & & & $\begin{array}{c}0.992 * * \\
(0.984-0.999)\end{array}$ \\
\hline $\begin{array}{l}\text { Branch in City of the } \\
\text { Home Office Only }\end{array}$ & $\begin{array}{c}0.629 \\
(0.34-1.18) \\
\end{array}$ & $\begin{array}{c}0.681 \\
(0.33-1.18) \\
\end{array}$ & $\begin{array}{c}0.634 \\
(0.33-1.20) \\
\end{array}$ & $\begin{array}{c}0.668 \\
(0.36-1.25) \\
\end{array}$ \\
\hline $\begin{array}{l}\text { Fraction Population in } \\
\text { Urban Areas }\end{array}$ & $\begin{array}{c}0.834 \\
(0.52-1.33)\end{array}$ & $\begin{array}{c}0.838 \\
(0.52-1.34)\end{array}$ & $\begin{array}{c}0.844 \\
(0.53-1.35)\end{array}$ & $\begin{array}{c}0.878 \\
(0.55-1.41)\end{array}$ \\
\hline $\begin{array}{l}\text { Number of Firms in the } \\
\text { County }\end{array}$ & $\begin{array}{c}0.925 \\
(0.84-1.02)\end{array}$ & $\begin{array}{c}0.924 \\
(0.84-1.02)\end{array}$ & $\begin{array}{c}0.926 \\
(0.84-1.02)\end{array}$ & $\begin{array}{c}0.999 \\
(0.99-1.01)\end{array}$ \\
\hline New Bank & $\begin{array}{c}0.718^{*} \\
(0.51-1.02)\end{array}$ & $\begin{array}{c}0.725^{*} \\
(0.51-1.02)\end{array}$ & $\begin{array}{c}0.730^{*} \\
(0.52-1.03)\end{array}$ & $\begin{array}{c}0.723^{*} \\
(0.51-1.02)\end{array}$ \\
\hline $\begin{array}{l}\text { Log Assets } \\
\text { (in } \$ 10,000 \text { ) }\end{array}$ & $\begin{array}{c}1.158 * * * \\
(1.04-1.29)\end{array}$ & $\begin{array}{c}1.160 * * * \\
(1.04-1.30)\end{array}$ & $\begin{array}{c}1.148 * * * \\
(1.02-1.29)\end{array}$ & $\begin{array}{c}1.118 * * \\
(1.01-1.24)\end{array}$ \\
\hline Loans to Assets & $\begin{array}{c}0.388^{*} \\
(0.15-1.03)\end{array}$ & $\begin{array}{c}0.388^{*} \\
(0.15-1.03)\end{array}$ & $\begin{array}{c}0.393^{*} \\
(0.15-1.05)\end{array}$ & $\begin{array}{c}0.374 * * \\
(0.14-0.99)\end{array}$ \\
\hline $\begin{array}{l}\text { Total Securities to } \\
\text { Assets }\end{array}$ & $\begin{array}{c}0.662 \\
(0.18-2.39)\end{array}$ & $\begin{array}{c}0.653 \\
(0.18-2.36)\end{array}$ & $\begin{array}{c}0.662 \\
(0.18-2.38)\end{array}$ & $\begin{array}{c}0.709 \\
(0.20-2.53)\end{array}$ \\
\hline Net Worth to Assets & $\begin{array}{c}0.786 \\
(0.22-2.76)\end{array}$ & $\begin{array}{c}0.788 \\
(0.22-2.76)\end{array}$ & $\begin{array}{c}0.817 \\
(0.23-2.87)\end{array}$ & $\begin{array}{c}0.853 \\
(0.24-2.99)\end{array}$ \\
\hline $\begin{array}{l}\text { Rediscounts to } \\
\text { Assets }\end{array}$ & $\begin{array}{c}0.064 * * \\
(0.01-0.61)\end{array}$ & $\begin{array}{c}0.063 * * \\
(0.01-0.60)\end{array}$ & $\begin{array}{c}0.063 * * \\
(0.01-0.61)\end{array}$ & $\begin{array}{c}0.069 * * \\
(0.01-0.67)\end{array}$ \\
\hline Commercial Bank & $\begin{array}{c}1.093 \\
(0.84-1.43)\end{array}$ & $\begin{array}{c}1.095 \\
(0.84-1.43)\end{array}$ & $\begin{array}{c}1.111 \\
(0.85-1.45)\end{array}$ & $\begin{array}{c}1.117 \\
(0.85-1.46)\end{array}$ \\
\hline $\begin{array}{l}\text { Commercial, Savings \& } \\
\text { Trust }\end{array}$ & $\begin{array}{c}0.937 \\
(0.58-1.52)\end{array}$ & $\begin{array}{c}0.939 \\
(0.57-1.55)\end{array}$ & $\begin{array}{c}1.007 \\
(0.62-1.65)\end{array}$ & $\begin{array}{c}1.053 \\
(0.64-1.73)\end{array}$ \\
\hline Maryland & $\begin{array}{c}1.373 \\
(0.90-2.09)\end{array}$ & $\begin{array}{c}1.369 \\
(0.90-2.09)\end{array}$ & $\begin{array}{c}1.405 \\
(0.92-2.14)\end{array}$ & $\begin{array}{c}1.399 \\
(0.92-2.31)\end{array}$ \\
\hline North Carolina & $\begin{array}{c}0.569 * * * \\
(0.39-0.82)\end{array}$ & $\begin{array}{c}0.567 * * * \\
(0.39-0.82)\end{array}$ & $\begin{array}{c}0.568 * * * \\
(0.39-0.83)\end{array}$ & $\begin{array}{c}0.571 * * * \\
(0.39-0.83)\end{array}$ \\
\hline Gamma & 0.521 & 0.521 & 0.523 & 0.522 \\
\hline Number Subjects & 650 & 650 & 650 & 650 \\
\hline Number Failures & 178 & 178 & 178 & 178 \\
\hline Log Likelihood & -434.6 & -434.8 & -437.0 & -437.9 \\
\hline
\end{tabular}

95\% confidence interval in parentheses

* - indicates significant at $10 \%$ level

$* *$ - indicates significant at $5 \%$ level

$* * *$ - indicates significant at $1 \%$ level 
Table 6

Duration Analysis by State

Dependent Variable: Time from June 30, 1929 until failure or March 1, 1933

\begin{tabular}{|c|c|c|c|c|}
\hline & All States & California & Maryland & North Carolina \\
\hline $\begin{array}{l}\text { Branch Outside } \\
\text { City Only }\end{array}$ & $\begin{array}{c}0.651 * * * \\
(0.48-0.89)\end{array}$ & $\begin{array}{c}.668 * * \\
(0.45-1.00)\end{array}$ & $\begin{array}{c}0.458 \\
(0.08-2.79)\end{array}$ & $\begin{array}{c}0.688^{*} \\
(0.45-1.05)\end{array}$ \\
\hline $\begin{array}{l}\text { Branch in City of the } \\
\text { Home Office Only }\end{array}$ & $\begin{array}{c}0.629 \\
(0.34-1.18) \\
\end{array}$ & $\begin{array}{c}0.674 \\
(0.33-1.39) \\
\end{array}$ & $\begin{array}{c}0.700 \\
(0.13-3.66) \\
\end{array}$ & $\begin{array}{c}0.283 \\
(0.05-1.76) \\
\end{array}$ \\
\hline $\begin{array}{l}\text { Fraction Population in } \\
\text { Urban Areas }\end{array}$ & $\begin{array}{c}0.834 \\
(0.52-1.33)\end{array}$ & $\begin{array}{c}0.995 \\
(0.47-2.08)\end{array}$ & $\begin{array}{c}0.211 \\
(0.00-9.85)\end{array}$ & $\begin{array}{c}0.933 \\
(0.50-1.73)\end{array}$ \\
\hline $\begin{array}{l}\text { Number of Firms in the } \\
\text { County }\end{array}$ & $\begin{array}{c}0.925 \\
(0.84-1.02) \\
\end{array}$ & $\begin{array}{c}0.946 \\
(0.87-1.04)\end{array}$ & $\begin{array}{c}1.494 \\
(0.15-14.5) \\
\end{array}$ & $\begin{array}{c}0.762 \\
(0.38-1.53) \\
\end{array}$ \\
\hline New Bank & $\begin{array}{c}0.718 * \\
(0.51-1.02) \\
\end{array}$ & $\begin{array}{c}0.761 \\
(0.54-1.07) \\
\end{array}$ & $\begin{array}{c}112000 \\
(0.00-999) \\
\end{array}$ & $\begin{array}{c}0.635 \\
(0.36-1.11) \\
\end{array}$ \\
\hline $\begin{array}{l}\text { Log Assets } \\
\text { (in } \$ 10,000)\end{array}$ & $\begin{array}{c}1.158 * * * \\
(1.04-1.29)\end{array}$ & $\begin{array}{c}1.249 * * \\
(1.05-1.49)\end{array}$ & $\begin{array}{c}1.142 \\
(0.58-2.25) \\
\end{array}$ & $\begin{array}{c}1.058 \\
(0.91-1.24) \\
\end{array}$ \\
\hline Loans to Assets & $\begin{array}{c}0.388^{*} \\
(0.15-1.03)\end{array}$ & $\begin{array}{c}0.506 \\
(0.10-2.44)\end{array}$ & $\begin{array}{c}0.232 \\
(0.00-19.9)\end{array}$ & $\begin{array}{c}0.509 \\
(0.15-1.77)\end{array}$ \\
\hline $\begin{array}{l}\text { Total Securities to } \\
\text { Assets }\end{array}$ & $\begin{array}{c}0.662 \\
(0.18-2.39) \\
\end{array}$ & $\begin{array}{c}0.414 \\
(0.10-1.74)\end{array}$ & $\begin{array}{c}2.413 \\
(0.01-715)\end{array}$ & $\begin{array}{c}10.03 \\
(0.62-161)\end{array}$ \\
\hline Net Worth to Assets & $\begin{array}{c}0.786 \\
(0.22-2.76)\end{array}$ & $\begin{array}{c}0.974 \\
(0.03-27.4)\end{array}$ & $\begin{array}{c}0.561 \\
(0.00-999)\end{array}$ & $\begin{array}{c}0.827 \\
(0.21-3.28)\end{array}$ \\
\hline $\begin{array}{l}\text { Rediscounts to } \\
\text { Assets }\end{array}$ & $\begin{array}{c}0.064 * * \\
(0.01-0.61)\end{array}$ & $\begin{array}{c}0.153 \\
(0.00-5.38)\end{array}$ & $\begin{array}{c}0.139 \\
(0.00-999)\end{array}$ & $\begin{array}{c}0.024 * * * \\
(0.00-0.39)\end{array}$ \\
\hline Commercial Bank & $\begin{array}{c}1.093 \\
(0.84-1.43)\end{array}$ & $\begin{array}{c}183 \\
(0.00-999)\end{array}$ & - & $\begin{array}{c}1.080 \\
(0.81-1.45)\end{array}$ \\
\hline $\begin{array}{l}\text { Commercial, Savings \& } \\
\text { Trust }\end{array}$ & $\begin{array}{c}0.937 \\
(0.58-1.52)\end{array}$ & $\begin{array}{c}0.805 \\
(0.40-1.59)\end{array}$ & $\begin{array}{c}0.435 \\
(0.09-2.11)\end{array}$ & $\begin{array}{c}2.475 \\
(0.77-7.95)\end{array}$ \\
\hline Maryland & $\begin{array}{c}1.373 \\
(0.90-2.09)\end{array}$ & & & \\
\hline North Carolina & $\begin{array}{c}0.569 * * * \\
(0.39-0.82)\end{array}$ & & & \\
\hline Gamma & 0.521 & 0.343 & 0.792 & 0.533 \\
\hline $\begin{array}{l}\text { Chi }^{2} \text { Test that State } \\
\text { Branch Coefficient = } \\
\text { Full Sample }\end{array}$ & & $\begin{array}{c}0.13 \\
\text { (no difference) }\end{array}$ & $\begin{array}{c}0.08 \\
\text { (no difference) }\end{array}$ & $\begin{array}{c}0.04 \\
\text { (no difference) }\end{array}$ \\
\hline $\begin{array}{l}\text { Chi }^{2} \text { Test that State } \\
\text { Coefficients = Full } \\
\text { Sample }\end{array}$ & & $\begin{array}{c}10.42 \\
\text { (no difference) }\end{array}$ & $\begin{array}{c}7.86 \\
\text { (no difference) }\end{array}$ & $\begin{array}{c}10.88 \\
\text { (no difference) }\end{array}$ \\
\hline Number Subjects & 650 & 181 & 136 & 333 \\
\hline Number Failures & 178 & 41 & 12 & 125 \\
\hline Log Likelihood & -434.6 & -89.1 & -46.0 & -281.8 \\
\hline
\end{tabular}

95\% confidence interval in parentheses

* - indicates significant at $10 \%$ level

** - indicates significant at 5\% level

*** - indicates significant at $1 \%$ level 
Table 7

Multi-Year Analysis with California

Dependent Variable: Time from June 30, 1929 until failure or March 1, 1933

\begin{tabular}{|c|c|}
\hline & $\begin{array}{l}\text { Survival } \\
\text { Length }\end{array}$ \\
\hline $\begin{array}{l}\text { Branch Outside } \\
\text { City Only }\end{array}$ & $\begin{array}{l}0.440 * * * \\
(0.25-0.78)\end{array}$ \\
\hline $\begin{array}{l}\text { Branch in City of the } \\
\text { Home Office Only }\end{array}$ & $\begin{array}{c}0.683 \\
(0.27-1.71)\end{array}$ \\
\hline $\begin{array}{l}\text { Fraction Population in } \\
\text { Urban Areas }\end{array}$ & $\begin{array}{c}0.386 * * * \\
(0.19-0.78)\end{array}$ \\
\hline $\begin{array}{l}\text { Number of Firms in the } \\
\text { County }\end{array}$ & $\begin{array}{c}0.866 \\
(0.32-2.31)\end{array}$ \\
\hline New Bank & $\begin{array}{c}0.791 \\
(0.50-1.24)\end{array}$ \\
\hline $\begin{array}{l}\text { Log Assets } \\
(\text { in } \$ 10,000)\end{array}$ & $\begin{array}{c}1.469 * * * \\
(1.15-1.88)\end{array}$ \\
\hline Loans to Assets & $\begin{array}{c}1.448^{*} \\
(0.25-8.34)\end{array}$ \\
\hline $\begin{array}{l}\text { Total Securities to } \\
\text { Assets }\end{array}$ & $\begin{array}{c}0.899 \\
(0.15-5.56) \\
\end{array}$ \\
\hline Net Worth to Assets & $\begin{array}{c}1.232 \\
(0.05-30.1)\end{array}$ \\
\hline $\begin{array}{l}\text { Rediscounts to } \\
\text { Assets }\end{array}$ & $\begin{array}{c}0.001 * * * \\
(0.00-0.08)\end{array}$ \\
\hline Commercial Bank & $\begin{array}{c}1.588 \\
(0.61-4.13)\end{array}$ \\
\hline $\begin{array}{l}\text { Commercial, Savings \& } \\
\text { Trust }\end{array}$ & $\begin{array}{c}0.596 \\
(0.24-1.42) \\
\end{array}$ \\
\hline Gamma & 0.373 \\
\hline Number Subjects & 183 \\
\hline Number Failures & 40 \\
\hline Log Likelihood & -74.9 \\
\hline
\end{tabular}

95\% confidence interval in parentheses

* - indicates significant at $10 \%$ level

** - indicates significant at 5\% level

*** - indicates significant at $1 \%$ level
Table 8

Testing Whether Size Matters

Dependent Variable: Time from June 30, 1929 until failure or March 1, 1933

\begin{tabular}{|c|c|}
\hline & $\begin{array}{c}\text { Survival } \\
\text { Length }\end{array}$ \\
\hline $\begin{array}{l}\text { Branch Outside } \\
\text { City Only }\end{array}$ & $\begin{array}{c}0.744 * * \\
(0.56-0.99)\end{array}$ \\
\hline $\begin{array}{l}\text { Branch in City of the } \\
\text { Home Office Only }\end{array}$ & $\begin{array}{c}0.778 \\
(0.43-1.41) \\
\end{array}$ \\
\hline $\begin{array}{l}\text { Fraction Population } \\
\text { in Urban Areas }\end{array}$ & $\begin{array}{c}0.943 \\
(0.59-1.49) \\
\end{array}$ \\
\hline $\begin{array}{l}\text { Number of Firms in } \\
\text { the County }\end{array}$ & $\begin{array}{c}0.999 * \\
(0.98-1)\end{array}$ \\
\hline New Bank & $\begin{array}{c}0.687 * * \\
(0.49-0.97)\end{array}$ \\
\hline Loans to Assets & $\begin{array}{c}0.400^{*} \\
(0.15-1.08)\end{array}$ \\
\hline $\begin{array}{l}\text { Total Securities to } \\
\text { Assets }\end{array}$ & $\begin{array}{c}0.745 \\
(0.20-2.73) \\
\end{array}$ \\
\hline Net Worth to Assets & $\begin{array}{c}0.576 \\
(0.18-1.90) \\
\end{array}$ \\
\hline $\begin{array}{l}\text { Rediscounts to } \\
\text { Assets }\end{array}$ & $\begin{array}{c}0.076 * * \\
(0.01-0.76)\end{array}$ \\
\hline Commercial Bank & $\begin{array}{c}1.037 \\
(0.80-1.35)\end{array}$ \\
\hline $\begin{array}{l}\text { Commercial, Savings } \\
\& \text { Trust }\end{array}$ & $\begin{array}{c}1.208 \\
(0.78-1.88)\end{array}$ \\
\hline Maryland & $\begin{array}{c}1.34 \\
(0.88-2.03)\end{array}$ \\
\hline North Carolina & $\begin{array}{c}0.526 * * * \\
(0.36-0.76)\end{array}$ \\
\hline Gamma & 0.523 \\
\hline Number Subjects & 650 \\
\hline Number Failures & 178 \\
\hline Log Likelihood & -439.5 \\
\hline
\end{tabular}

$95 \%$ confidence interval in parentheses

* - indicates significant at $10 \%$ level

** - indicates significant at 5\% level

$* * *$ - indicates significant at $1 \%$ level 
Table 9

Survival Analysis Adjusting for Expansion over the Past 5 Years

Dependent Variable: Time until the bank is closed

\begin{tabular}{|c|c|c|c|c|}
\hline & Unadjusted & $\begin{array}{c}\text { Percent } \\
\text { Expansion of } \\
\text { Assets } \\
\end{array}$ & $\begin{array}{l}\text { Percent Increase } \\
\text { in Branches }\end{array}$ & $\begin{array}{l}\text { Bank Changes } \\
\text { From a Unit Bank } \\
\text { to Branch Bank }\end{array}$ \\
\hline $\begin{array}{l}\text { Branch Outside } \\
\text { City Only }\end{array}$ & $\begin{array}{c}0.670 * * \\
(0.48-0.93)\end{array}$ & $\begin{array}{c}0.670 * * \\
(0.48-0.93)\end{array}$ & $\begin{array}{c}0.654 * * \\
(0.46-0.94)\end{array}$ & $\begin{array}{c}0.643^{* *} \\
(0.46-0.91)\end{array}$ \\
\hline $\begin{array}{l}\text { Expansion } \\
\text { Adjustment }\end{array}$ & & $\begin{array}{c}0.994 \\
(0.90-1.09)\end{array}$ & $\begin{array}{c}1.100 \\
(0.60-2.03)\end{array}$ & $\begin{array}{c}1.251 \\
(0.67-2.32)\end{array}$ \\
\hline $\begin{array}{l}\text { Branch in City of the } \\
\text { Home Office Only }\end{array}$ & $\begin{array}{c}0.631 \\
(0.34-1.18)\end{array}$ & $\begin{array}{c}0.630 \\
(0.34-1.18)\end{array}$ & $\begin{array}{c}0.637 \\
(0.34-1.19)\end{array}$ & $\begin{array}{c}0.560 \\
(0.28-1.13)\end{array}$ \\
\hline $\begin{array}{l}\text { Fraction Population in } \\
\text { Urban Areas }\end{array}$ & $\begin{array}{c}0.769 \\
(0.47-1.25)\end{array}$ & $\begin{array}{c}0.769 \\
(0.47-1.25)\end{array}$ & $\begin{array}{c}0.773 \\
(0.47-1.25)\end{array}$ & $\begin{array}{c}0.771 \\
(0.48-1.25)\end{array}$ \\
\hline $\begin{array}{l}\text { Number of Firms in } \\
\text { the County }\end{array}$ & $\begin{array}{c}0.948 \\
(0.85-1.06)\end{array}$ & $\begin{array}{c}0.948 \\
(0.85-1.06)\end{array}$ & $\begin{array}{c}0.947 \\
(0.85-1.06)\end{array}$ & $\begin{array}{c}0.947 \\
(0.85-1.06)\end{array}$ \\
\hline $\begin{array}{l}\text { Log Assets } \\
(\text { in } \$ 10,000)\end{array}$ & $\begin{array}{c}1.157 * * \\
(1.03-1.29) \\
\end{array}$ & $\begin{array}{c}1.157 * * \\
(1.03-1.29) \\
\end{array}$ & $\begin{array}{c}1.154 * * \\
(1.03-1.29) \\
\end{array}$ & $\begin{array}{c}1.158 * * \\
(1.03-1.30)\end{array}$ \\
\hline Loans to Assets & $\begin{array}{c}0.420 * \\
(0.16-1.12)\end{array}$ & $\begin{array}{c}0.421 * \\
(0.16-1.12)\end{array}$ & $\begin{array}{c}0.419 * \\
(0.16-1.11)\end{array}$ & $\begin{array}{c}0.418 * \\
(0.16-1.11)\end{array}$ \\
\hline $\begin{array}{l}\text { Total Securities to } \\
\text { Assets }\end{array}$ & $\begin{array}{c}0.709 \\
(0.19-2.62)\end{array}$ & $\begin{array}{c}0.709 \\
(0.19-2.62)\end{array}$ & $\begin{array}{c}0.709 \\
(0.19-2.63)\end{array}$ & $\begin{array}{c}0.704 \\
(0.19-2.60)\end{array}$ \\
\hline Net Worth to Assets & $\begin{array}{c}0.821 \\
(0.23-2.97)\end{array}$ & $\begin{array}{c}0.819 \\
(0.23-2.97)\end{array}$ & $\begin{array}{c}0.819 \\
(0.23-2.96)\end{array}$ & $\begin{array}{c}0.812 \\
(0.22-2.94)\end{array}$ \\
\hline $\begin{array}{l}\text { Rediscounts to } \\
\text { Assets }\end{array}$ & $\begin{array}{c}0.052 * * \\
(0.00-0.57)\end{array}$ & $\begin{array}{c}0.052 * * \\
(0.00-0.57)\end{array}$ & $\begin{array}{c}0.052 * * \\
(0.00-0.57)\end{array}$ & $\begin{array}{c}0.053 * * \\
(0.00-0.58)\end{array}$ \\
\hline Commercial Bank & $\begin{array}{c}1.087 \\
(0.83-1.42) \\
\end{array}$ & $\begin{array}{c}1.087 \\
(0.83-1.42) \\
\end{array}$ & $\begin{array}{c}1.086 \\
(0.83-1.42)\end{array}$ & $\begin{array}{c}1.088 \\
(0.83-1.43)\end{array}$ \\
\hline $\begin{array}{l}\text { Commercial, Savings } \\
\text { \& Trust }\end{array}$ & $\begin{array}{c}1.005 \\
(0.61-1.65)\end{array}$ & $\begin{array}{c}1.009 \\
(0.61-1.66)\end{array}$ & $\begin{array}{c}1.002 \\
(0.61-1.65)\end{array}$ & $\begin{array}{c}1.014 \\
(0.62-1.67)\end{array}$ \\
\hline Maryland & $\begin{array}{c}1.272 \\
(0.83-1.95)\end{array}$ & $\begin{array}{c}1.273 \\
(0.83-1.95)\end{array}$ & $\begin{array}{c}1.272 \\
(0.83-1.95)\end{array}$ & $\begin{array}{c}1.256 \\
(0.82-1.92)\end{array}$ \\
\hline North Carolina & $\begin{array}{c}0.576 * * * \\
(0.39-0.84)\end{array}$ & $\begin{array}{c}0.576 * * * \\
(0.39-0.84) \\
\end{array}$ & $\begin{array}{c}0.578 * * * \\
(0.40-0.84)\end{array}$ & $\begin{array}{c}0.575 * * * \\
(0.39-0.84) \\
\end{array}$ \\
\hline Gamma & 0.514 & 0.514 & 0.514 & 0.514 \\
\hline Number Subjects & 601 & 601 & 601 & 601 \\
\hline Number Failures & 161 & 161 & 161 & 161 \\
\hline Log Likelihood & -395.7 & -395.7 & -395.7 & -395.4 \\
\hline
\end{tabular}

95\% confidence interval in parentheses

* - indicates significant at $10 \%$ level

$* *$ - indicates significant at 5\% level

*** - indicates significant at $1 \%$ level 
Table 10

Reserve Deposit Ratio for Branch Banks after Adjusting for Bank Characteristics

Dependent Variable: Reserves to Demand Deposits

\begin{tabular}{|c|c|}
\hline & All Banks \\
\hline $\begin{array}{l}\text { Branch Outside } \\
\text { City Only }\end{array}$ & $\begin{array}{c}-0.476^{* *} \\
(0.23)\end{array}$ \\
\hline $\begin{array}{l}\text { Branch in City of the Home } \\
\text { Office Only }\end{array}$ & $\begin{array}{l}0.483 \\
(0.90)\end{array}$ \\
\hline $\begin{array}{l}\text { Fraction Population in Urban } \\
\text { Areas }\end{array}$ & $\begin{array}{c}-0.481 * * \\
(0.24)\end{array}$ \\
\hline Number of Firms in the County & $\begin{array}{l}-4 e-6 \\
(7 e-6)\end{array}$ \\
\hline Agricultural Diversity Index & $\begin{array}{l}0.643 \\
(0.87) \\
\end{array}$ \\
\hline New Bank & $\begin{array}{l}-0.132 \\
(0.09) \\
\end{array}$ \\
\hline $\begin{array}{l}\text { Log Assets } \\
\text { (in } \$ 10,000 \text { ) }\end{array}$ & $\begin{array}{l}0.258 * \\
(0.14)\end{array}$ \\
\hline Loans to Assets & $\begin{array}{l}-3.841 \\
(0.60)\end{array}$ \\
\hline Net Worth to Assets & $\begin{array}{l}0.203 \\
(0.71) \\
\end{array}$ \\
\hline $\begin{array}{l}\text { Rediscounts to } \\
\text { Assets }\end{array}$ & $\begin{array}{c}-0.046 \\
(0.69) \\
\end{array}$ \\
\hline Commercial Bank & $\begin{array}{l}0.203 * * \\
(0.10)\end{array}$ \\
\hline Commercial, Savings \& Trust & $\begin{array}{c}-0.944 * \\
(0.51)\end{array}$ \\
\hline Maryland & $\begin{array}{l}1.088 * * * \\
(0.21)\end{array}$ \\
\hline North Carolina & $\begin{array}{c}0.274 * * \\
(0.11)\end{array}$ \\
\hline Constant & $\begin{array}{c}1.800^{* *} \\
(0.82)\end{array}$ \\
\hline Number Subjects & 650 \\
\hline Adjusted $\mathrm{R}^{2}$ & 0.25 \\
\hline
\end{tabular}

standard error in parentheses

* - indicates significant at $10 \%$ level

** - indicates significant at $5 \%$ level

$* * *$ - indicates significant at $1 \%$ level 
Table 11

Reasons for Failure of Unit and Branch Banks - California Banks

\begin{tabular}{|c|c|c|c|c|c|c|c|c|c|}
\hline & \multirow{2}{*}{$\begin{array}{l}\text { Total } \\
\text { Failures }\end{array}$} & \multicolumn{8}{|c|}{ Reasons for Failure* } \\
\hline & & A & $\mathrm{B}$ & $\mathrm{C}$ & $\mathrm{D}$ & $\mathrm{E}$ & $\mathrm{F}$ & $\mathrm{G}$ & $\mathrm{H}$ \\
\hline $\begin{array}{l}\text { Branch in Home } \\
\text { City Only }\end{array}$ & 2 & $\begin{array}{c}1 \\
(50 \%)\end{array}$ & 0 & $\begin{array}{c}1 \\
(50 \%)\end{array}$ & $\begin{array}{c}2 \\
(100 \%)\end{array}$ & 0 & 0 & 0 & 0 \\
\hline $\begin{array}{l}\text { Branch Outside } \\
\text { Home City }\end{array}$ & 8 & $\begin{array}{c}1 \\
(12 \%)\end{array}$ & $\begin{array}{c}1 \\
(12 \%)\end{array}$ & $\begin{array}{c}5 \\
(62 \%)\end{array}$ & $\begin{array}{c}3 \\
(38 \%)\end{array}$ & $\begin{array}{c}1 \\
(12 \%)\end{array}$ & 0 & $\begin{array}{c}8 \\
(100 \%)\end{array}$ & $\begin{array}{c}4 \\
(50 \%)\end{array}$ \\
\hline Unit Banks & 33 & $\begin{array}{c}9 \\
(27 \%)\end{array}$ & $\begin{array}{c}2 \\
(6 \%)\end{array}$ & $\begin{array}{c}14 \\
(42 \%)\end{array}$ & $\begin{array}{c}15 \\
(45 \%)\end{array}$ & $\begin{array}{c}7 \\
(21 \%)\end{array}$ & $\begin{array}{c}7 \\
(21 \%)\end{array}$ & $\begin{array}{c}14 \\
(42 \%)\end{array}$ & $\begin{array}{c}17 \\
(52 \%)\end{array}$ \\
\hline
\end{tabular}

*A. Mismanagement B. Dishonesty of Officer or Employee, resulting in defalcation C. Frozen assets D. Local or General Depression E. Adversely affected by the failure of another bank F. Excessive overhead or causes traceable to the inception of the venture G. Heavy Cash Withdrawal H. Bond Depreciation 
Table 12

Survival Adjusted for Portfolio Choice Mergers Truncated - California Only

Dependent Variable: Time until the bank is closed

\begin{tabular}{|c|c|c|c|}
\hline & Unadjusted & $\begin{array}{c}\text { Adjusted } \\
\text { Using Nearby Failure } \\
\text { Indicator }\end{array}$ & $\begin{array}{c}\text { Adjusted Using } \\
\text { Heavy Withdrawal } \\
\text { Indicator }\end{array}$ \\
\hline $\begin{array}{l}\text { Branch Outside } \\
\text { City Only }\end{array}$ & $\begin{array}{c}.668 * * \\
(0.45-1.00)\end{array}$ & $\begin{array}{c}0.729 \\
(0.49-1.09)\end{array}$ & $\begin{array}{c}0.764 \\
(0.51-1.15)\end{array}$ \\
\hline Portfolio Residual & & $\begin{array}{c}0.980 \\
(0.88-1.09)\end{array}$ & $\begin{array}{c}0.979 \\
(0.89-1.08)\end{array}$ \\
\hline $\begin{array}{l}\text { Interaction: Residual \& } \\
\text { Bank Run Indicator }\end{array}$ & & $\begin{array}{c}1.604 * \\
(0.98-2.64)\end{array}$ & $\begin{array}{c}1.641 * * \\
(1.02-2.64)\end{array}$ \\
\hline $\begin{array}{l}\text { Branch in City of the } \\
\text { Home Office Only }\end{array}$ & $\begin{array}{c}0.674 \\
(0.33-1.39) \\
\end{array}$ & $\begin{array}{c}0.704 \\
(0.34-1.45) \\
\end{array}$ & $\begin{array}{c}0.697 \\
(0.34-1.43) \\
\end{array}$ \\
\hline $\begin{array}{l}\text { Fraction Population in } \\
\text { Urban Areas }\end{array}$ & $\begin{array}{c}0.995 \\
(0.47-2.08)\end{array}$ & $\begin{array}{c}1.016 \\
(0.49-2.09)\end{array}$ & $\begin{array}{c}1.055 \\
(0.50-2.22)\end{array}$ \\
\hline $\begin{array}{l}\text { Number of Firms in } \\
\text { the County }\end{array}$ & $\begin{array}{c}0.946 \\
(0.87-1.04)\end{array}$ & $\begin{array}{c}0.999 \\
(0.99-1.00)\end{array}$ & $\begin{array}{c}0.999 \\
(0.99-1.00)\end{array}$ \\
\hline New Bank & $\begin{array}{c}0.761 \\
(0.54-1.07)\end{array}$ & $\begin{array}{c}0.760 \\
(0.54-1.07)\end{array}$ & $\begin{array}{c}0.749 * \\
(0.53-1.05)\end{array}$ \\
\hline $\begin{array}{l}\text { Log Assets } \\
\text { (in } \$ 10,000)\end{array}$ & $\begin{array}{c}1.249 * * \\
(1.05-1.49)\end{array}$ & $\begin{array}{c}1.262 * * \\
(1.06-1.51)\end{array}$ & $\begin{array}{c}1.243 * * \\
(1.04-1.48) \\
\end{array}$ \\
\hline Loans to Assets & $\begin{array}{c}0.506 \\
(0.10-2.44)\end{array}$ & $\begin{array}{c}0.178 * \\
(0.02-1.29)\end{array}$ & $\begin{array}{c}0.467 \\
(0.10-2.28)\end{array}$ \\
\hline $\begin{array}{l}\text { Total Securities to } \\
\text { Assets }\end{array}$ & $\begin{array}{c}0.414 \\
(0.10-1.74)\end{array}$ & $\begin{array}{c}0.167 * * \\
(0.03-0.97)\end{array}$ & $\begin{array}{c}0.426 \\
(0.10-1.75)\end{array}$ \\
\hline Net Worth to Assets & $\begin{array}{c}0.974 \\
(0.03-27.4)\end{array}$ & $\begin{array}{c}0.865 \\
(0.03-21.7)\end{array}$ & $\begin{array}{c}0.789 \\
(0.03-19.4)\end{array}$ \\
\hline $\begin{array}{l}\text { Rediscounts to } \\
\text { Assets }\end{array}$ & $\begin{array}{c}0.153 \\
(0.00-5.38) \\
\end{array}$ & $\begin{array}{c}0.185 \\
(0.01-6.08) \\
\end{array}$ & $\begin{array}{c}0.159 \\
(0.00-5.37) \\
\end{array}$ \\
\hline Commercial Bank & $\begin{array}{c}183 \\
(0.00-999)\end{array}$ & $\begin{array}{c}117 \\
(0.00-999)\end{array}$ & $\begin{array}{c}188 \\
(0.00-999)\end{array}$ \\
\hline $\begin{array}{l}\text { Commercial, Savings } \\
\& \text { Trust }\end{array}$ & $\begin{array}{c}0.805 \\
(0.40-1.59) \\
\end{array}$ & $\begin{array}{c}0.741 \\
(0.38-1.46) \\
\end{array}$ & $\begin{array}{c}0.748 \\
(0.38-1.47) \\
\end{array}$ \\
\hline Gamma & 0.347 & 0.334 & 0.335 \\
\hline Number Subjects & 181 & 181 & 181 \\
\hline Number Failures & 41 & 41 & 41 \\
\hline Log Likelihood & -89.1 & -87.4 & -87.1 \\
\hline
\end{tabular}

95\% confidence interval in parentheses

* - indicates significant at $10 \%$ level

** - indicates significant at 5\% level

$* * *$ - indicates significant at $1 \%$ level 
Figure 1

Kaplan Meier Survival Function for All States by Bank Type

Fraction Banks Remaining

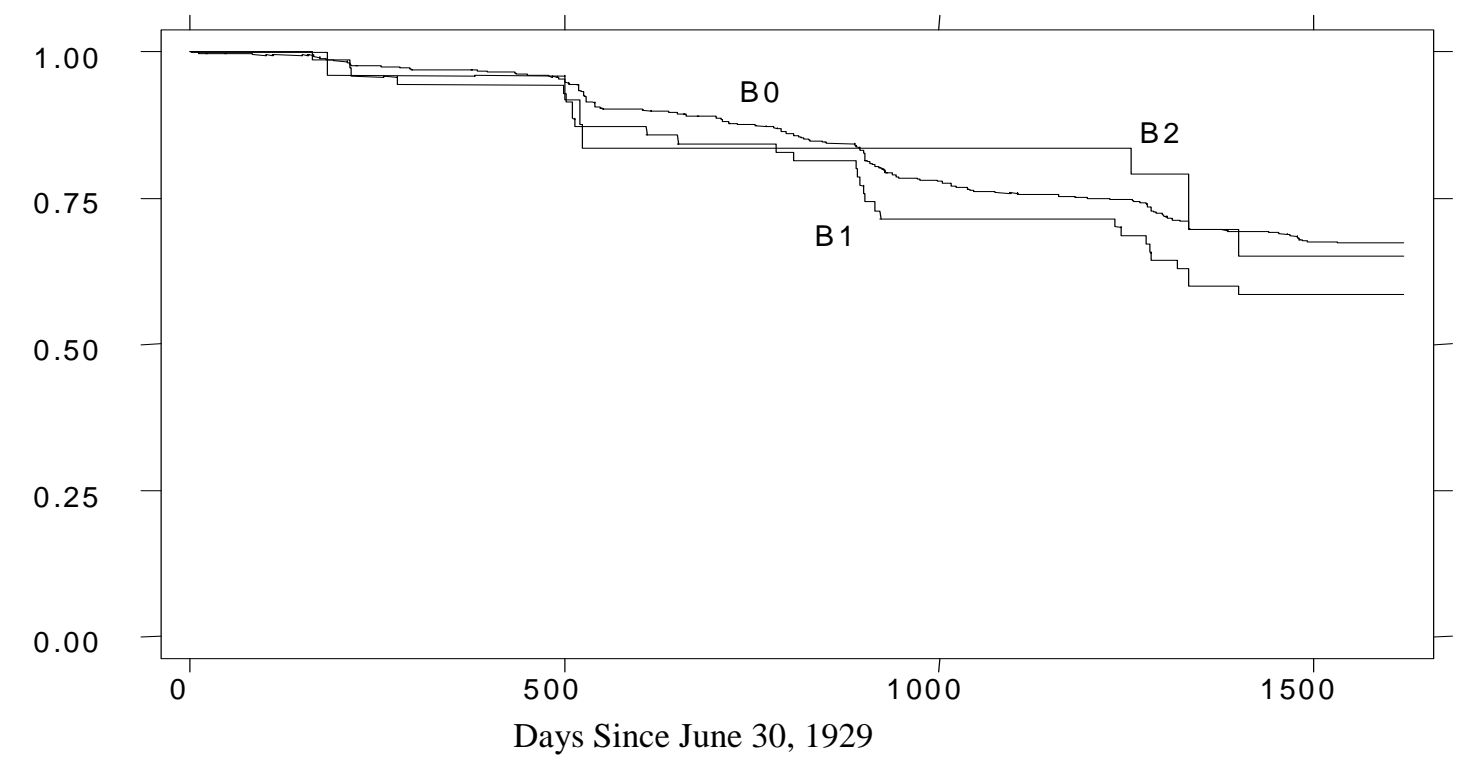

B0 = unit banks $\quad$ B1 $=$ outside branching banks $\quad$ B2 $=$ home branching banks 